Postprint of: Journal of Hazardous Materials, volume 186, issues 2-3, 28 February 2011, pages 1930-1941

\title{
Examination of competitive lanthanide sorption onto smectites and its significance in the management of radioactive waste
}

Evgeny Galunin (a), María D. Alba (b), Maria J. Santos (c), Taufik Abrão (b), Miquel Vidal (a)

a Departament de Química Analítica, Universitat de Barcelona, Martí i Franqués 1-11, 08028 Barcelona, Spain

b Instituto de Ciencia de Materiales de Sevilla, Consejo Superior de Investigaciones Científicas Universidad de Sevilla, Av. Américo Vespucio 49, 41092 Sevilla, Spain

c Departamento de Química, Universidade Estadual de Londrina, Londrina, PR 86051-990, Brazil

\begin{abstract}
The competitive effect of La and Lu (analogues of radionuclides appearing in radioactive waste) in the sorption in four smectites was examined. Sorption and desorption distribution coefficients (Kd; Kd,des), and desorption rates (Rdes) were determined from batch tests in two media: deionized water and, to consider the influence of cement leachates, $0.02 \mathrm{~mol} \mathrm{~L}-1 \mathrm{Ca}$. The competitive effect was lower when high-affinity sites were available, as in the water medium at the lowest range of initial lanthanide concentration, with high Kd for La and for Lu (5-63 × 104 $\mathrm{L} \mathrm{kg-1).} \mathrm{Lower} \mathrm{Kd} \mathrm{was} \mathrm{measured} \mathrm{at} \mathrm{higher} \mathrm{initial} \mathrm{concentrations} \mathrm{and} \mathrm{in} \mathrm{the} \mathrm{Ca} \mathrm{medium,} \mathrm{where}$ Lu showed a stronger competitive effect. This was confirmed by fitting the sorption data to a two-solute Langmuir isotherm. The desorption data indicated that sorption was virtually irreversible for the scenarios with high sorption, with an excellent correlation between $\mathrm{Kd}$ and $\mathrm{Kd}$, des ( $\mathrm{R} 2$ around 0.9 for the two lanthanides). Assuming that radioactive waste is a mixture of radionuclides, and that $\mathrm{Ca}$ ions will be provided by the cement leachates, this would reduce the retention capacity of clay engineered barriers.
\end{abstract}

\section{Keywords}

Lanthanides; Sorption; Smectitic clays; Engineered barriers; Radioactive waste

\section{Introduction}

A deep geological repository (DGR) is the optimal storage for long-term radioactive waste management [1], [2] and [3]. Within the DGR, clay engineered barriers, usually placed between the metal canister containing the radioactive waste and external concrete barriers play a significant role in radionuclide retention. Clays have low permeability and diffusivity, high sorption capacity and strong buffering properties [4], [5] and [6]. Among the clays used for this purpose, smectites are generally considered to be the most efficient, due to their ability to 
undergo strain without fracturing, their low hydraulic conductivity, high cation sorption capacity, and ability to expand and enter into close contact with both waste and rock [7]. Apart from clay engineered barriers, the DGR may include concrete bulkheads in contact with the clay backfill. Cement leachates may react with the clays, which would compromise the isolation potential of the clay and the strength of the concrete [8]. In addition, cement degradation releases alkaline calcium fluids causing geochemical transformations and modifying the clay [9] and [10]. Spent nuclear fuel contains a number of fission products, and radionuclides with high activity concentrations and long half-lives - mainly actinides and their daughter products dominate the radiotoxicity of high-level waste [11]. To study actinide sorption-desorption processes at laboratory level, lanthanides have been used as structural and chemical analogues [12] and [13].

Factors such as $\mathrm{pH}$, the nature of clay mineral interlayer cations, and ionic strength affect lanthanide sorption-desorption processes in clays [14], [15], [16] and [17]. Two main sorption mechanisms have been highlighted for lanthanides: surface complexation at the edges of the clay particles (inner-sphere interaction), and cationic exchange (outer-sphere interaction). The predominance of one mechanism over the other may depend on the lanthanide and its concentration [18], [19], [20] and [21]. Whereas some authors conclude that sorption is completely reversible [22], others suggest that it may be partially irreversible due to the strong attractive forces between trivalent lanthanide cations and clay interlayer exchange sites [23] and [24].

While there are limited data on lanthanide sorption on smectites, few authors deal with sorption studies of mixture of lanthanides, which are required to simulate scenarios for radioactive waste management. In this regard, reported data indicate that competition between the lanthanides of similar valence state and hydrolysis behavior may occur in smectites [21]. Therefore, this study aims to complete previous work on lanthanide sorption on smectites [25] and [26]. Whereas in these works the sorption-desorption pattern of lanthanides in smectites was individually evaluated with single lanthanide solutions, here we evaluate the effect of lanthanide competition on the sorption-desorption processes. As the preferential sorption-desorption mechanisms of lanthanides may vary along the lanthanide series [27] and [28], the lightest (La) and the heaviest (Lu) lanthanides were chosen to evaluate changes in the lanthanide sorption over a range of lanthanide concentration ratios. Two sorption media with different Ca concentrations were also tested to simulate the DGR conditions. The smectites examined here include hectorite, Otay montmorillonite, and MX80 and FEBEX bentonites, which are either candidates for clay engineered barriers, or already in use in experiments dealing with radioactive waste repositories. Sorption data were also fitted with two-solute Langmuir equation to facilitate comparison of the scenarios examined.

\section{Materials and methods}

\subsection{Clay samples}

Four smectites (FEBEX bentonite - FEBEX; hectorite - HEC; MX80 bentonite - MX80, and Otay montmorillonite - SCa-3) were used. Table 1 summarizes the main clay characteristics [29], [30], 
[31] and [32]. These clays are 2:1 phyllosilicates and consist of layers made up by the condensation of a central octahedral sheet and two tetrahedral sheets, one on each side. Octahedral compositions depend on the octahedral occupancy, which can either be a full occupancy of the sheet if the cations are Mg (trioctahedral clays - HEC) or an occupancy of twothirds of the available positions if the cations are Al (dioctahedral clays - FEBEX, MX80, SCa-3). In all the samples, the $<2 \mu \mathrm{m}$-fraction was obtained, and the carbonates and organic matter were eliminated in order to ensure purity.

\subsection{Sorption-desorption experiments}

Batch sorption tests were carried out in $50 \mathrm{~mL}$ centrifuge tubes, with equilibration of $0.2 \mathrm{~g}$ of clay with $30 \mathrm{~mL}$ of the solutions that contained the mixture of lanthanides at a given concentration in two ionic media: deionised water (Milli-Q Reagent Water System from Millipore, resistivity of $>18 \mathrm{M} \Omega \mathrm{cm}-1$ ) and $0.02 \mathrm{~mol} \mathrm{L-1} \mathrm{Ca} \mathrm{(Ca(NO3)2)} \mathrm{from} \mathrm{Prolabo,} \mathrm{RP}$ Normapur, analytical grade) at an initial $\mathrm{pH}$ of 7. Lanthanide solutions were prepared from $\mathrm{La}(\mathrm{NO} 3) 3$ and Lu(NO3)3 (99.9\%, Aldrich). Table 2 shows the concentrations of the theoretical initial La and Lu concentrations used in the mixture solutions. The experimental design provided the sorption isotherms of a target lanthanide at two concentration ranges and at two concentrations of the competitive lanthanide. The solutions were equilibrated with the clay samples by end-over-end shaking at $30 \mathrm{rpm}$ at room temperature for $24 \mathrm{~h}$. The final suspensions were centrifuged at 10,000 rpm for 25 min (Hettich Universal $30 \mathrm{~F}$, with a rotor E1174) and filtered (Whatman 41, $0.22 \mu \mathrm{m}$ ). The supernatants were collected in polyethylene bottles, diluted with $1 \% \mathrm{HNO} 3$ and stored at $4{ }^{\circ} \mathrm{C}$ until analysis.

Batch desorption tests were performed the day after the sorption tests, by bringing the clay residues from the sorption tests into contact with the two ionic media mentioned above, but without the lanthanide. The other experimental conditions were as described for the sorption tests.

\subsection{Scanning electron microscopy (SEM) and energy dispersion X-ray (EDX) analyses.}

The morphology of the samples resulting from the sorption experiments was analyzed by a Scanning Electron Microscope using JEOL equipment (Model JSM 5400) at $20 \mathrm{kV}$. An energy dispersive X-ray (EDX) system (Oxford Link ISIS) was fitted to the SEM equipment to perform chemical analysis of the samples using a Si/Li detector with a Be window.

\subsection{Determination of $L a$ and $L u$ in the solutions derived from sorption experiments}

Lanthanide concentrations in the initial solutions and in the supernatants were analyzed by ICPOES (Perkin-Elmer Optima-3200RL) for the concentration range over 1.5 meq L-1, and by ICPMS (Perkin-Elmer Elan-6000) for lower concentrations. The wavelengths $(\mathrm{nm})$ used in the ICPOES measurements were 384.902 (La) and 261.542 (Lu), which corresponded to the 139La and 175Lu isotopes in the ICP-MS measurements. Calibration curves were prepared in $1 \%$ HNO3, using $103 R \mathrm{R}$ as an internal standard, with a concentration of $10 \mu \mathrm{g} \mathrm{L-1,} \mathrm{to} \mathrm{correct} \mathrm{instabilities} \mathrm{in}$ the ICP-MS measurements. Concentration ranges of the standards were $0.05-100 \mathrm{mg} \mathrm{L}-1$ for La and $0.01-100 \mathrm{mg} \mathrm{L}-1$ for Lu). The detection limit for the ICP-OES is $50 \mu \mathrm{g} \mathrm{L}-1$ for La and $10 \mu \mathrm{g}$ $\mathrm{L}-1$ for $\mathrm{Lu}$, and for the ICP-MS is $5 \mathrm{ng} \mathrm{L}-1$ for both lanthanides. 


\subsection{Calculation of sorption-desorption parameters}

From the sorption-desorption tests, and following ICP-OES and ICP-MS measurements, we calculated the initial lanthanide concentration (Cinit, meq L-1), the equilibrium concentration in the supernatant after sorption experiments (Ceq, meq $L-1$ ), and the equilibrium concentration in the supernatant after desorption experiments (Ceq,des, meq L-1). Based on these data, the following parameters, required to examine lanthanide sorption-desorption in the smectites selected, were calculated:

a) sorption distribution coefficient $(K d, L \mathrm{~kg}-1)$ :

$$
K_{\mathrm{d}}=\frac{\left(C_{\text {init }}-C_{\mathrm{eq}}\right) V}{C_{\mathrm{eq}} m}
$$

where $\mathrm{V}$ is the liquid phase volume, in $\mathrm{L}$; and $\mathrm{m}$ is the clay sample weight, in $\mathrm{kg}$.

b) desorption distribution coefficient (Kd,des, L kg-1):

$K_{\mathrm{d}, \mathrm{des}}=\frac{\left(C_{\text {init }}-C_{\mathrm{eq}}-C_{\mathrm{eq}, \mathrm{des}}\right) V}{C_{\text {eq,des }} m}$

c) desorption rate (Rdes, \%):

$$
R_{\mathrm{des}}=\frac{C_{\mathrm{eq}, \mathrm{des}}}{C_{\text {init }}-C_{\mathrm{eq}}} \times 100
$$

\subsection{Use of the two-solute Langmuir equation to fit sorption data}

The Langmuir equation was used to fit sorption data, although it makes a number of assumptions - e.g., sorption takes place at specific homogeneous sites, the sorption system is monolayer and the interactions of sorbed species are not considered; the sorption energy is constant over the entire surface [33]. When dealing with sorption data with a mixture of analytes, an extended form of the Langmuir model, as shown in Eq. (4), can be used to analyze the two-solute sorption [34] and [35]. This equation allows predictions of the concentration of solute i sorbed (Csorb,i) in the presence of sorption-competitive solutes:

$$
C_{\mathrm{sorb}, i}=\frac{b_{i} K_{i} C_{\mathrm{eq}, i}}{1+\sum_{j=1}^{N} K_{j} C_{\mathrm{eq}, j}}
$$

where Ceq, $\mathrm{i}$ is the equilibrium concentration of solute $\mathrm{i}$ in a mixture of $\mathrm{N}$ solutes, and bi and $\mathrm{Ki}$ constants are empirical sorption parameters obtained from the fitting of the isotherms. $b$ represents the maximum sorption capacity determined by the reactive surface sites in an ideal monolayer system, and $\mathrm{K}$ represents the bonding energy associated with a $\mathrm{pH}$-dependent equilibrium constant. Here we used the two-solute Langmuir model to fit the sorption data and to plot the sorption data in three-dimensional space. The three-dimensional format adds information to that of the two-dimensional fitting, and it is only rarely applied to fit competitive sorption data [36]. 


\subsection{Data treatment}

The sorption-desorption tests were performed with 3-6 replicates, which allowed the calculation of the mean and standard deviations of the derived parameters. The sorption data fittings were made using sftool (interactive environment for fitting curves to $\mathrm{n}$-dimensional data), which is included in the mathematical software Matlab 7.10.0 [37]. The fitting coefficients were taken for positive values, with confidence limits $\geq 95 \%$, using non-linear least squares fitting with the Trust-region or Levenberg-Marquardt algorithm option. In all fittings, the squared correlation coefficients (R2) were close to 1.0 with low residual mean square error (RMSE).

\section{Results and discussion}

\subsection{Description of lanthanide sorption in competitive scenarios}

Table 3, Table 4, Table 5 and Table 6 summarize the sorption data for La and Lu in the two media for all the smectites, including the lanthanide initial (Cinit (La), Cinit (Lu)) and sorbed concentrations (Csorb(La), Csorb(Lu)), and the resulting pH in the supernatants after the sorption. There was a general decrease in the Kd values of the lanthanides with increasing initial concentrations in the two concentration ranges tested (from 0.01 to 1 meq $L-1$, and from 0.1 to 9 meq L-1), at a constant concentration of the competitive lanthanide. Moreover, the range of the $\mathrm{Kd}$ values obtained within the high concentration range was lower than that obtained for the low concentration range. This trend was observed for all clays and for the two lanthanides in the two media, similarly to what was previously observed in the absence of a competitive lanthanide [26]. Changes in the $\mathrm{Kd}$ due to the variation of the initial lanthanide concentration were higher than those due to changes in the clays, although the Kd values in the MX80 and FEBEX bentonites were consistently the lowest and the highest in the water medium, respectively.

The medium composition influenced the Kd quantification: the Kd values in the Ca medium were systematically lower than in the water medium, with decreases that were nearly two orders of magnitude in some cases, especially when La was the target solute. The only exception was MX80 clay for the low lanthanide concentration range. The results were in agreement with the previous data reported for single sorption of La and Lu [26]. In that case, the effect of Ca on the quantification of the $\mathrm{Kd}$ was partially explained in terms of the potential competitive influence of the Ca ions, which tend to be sorbed at interlattice sites, and then displace the lanthanides to less specific sites, as the sorbed concentration of Ca was much higher than those of the two lanthanides [26].

In the water medium, the $\mathrm{Kd}(\mathrm{La})$ were generally higher than the $\mathrm{Kd}(\mathrm{Lu})$ in the HEC and MX80 clays, whereas the opposite was observed for the SCa-3, the FEBEX showing intermediate behavior (the $\mathrm{Kd}(\mathrm{La})$ was higher only at the lowest lanthanide concentration). This finding can be explained by the fact that Lu is a cation with a greater charge density and lower radius than $\mathrm{La}$, and thus with a stronger electrostatic attraction for a ligand, which affects the ionic exchange dealing with the sorption at sites with a lower sorption affinity. The exceptions observed in clays with isomorphic substitutions in the octahedral sheets, such as MX80 and HEC, can be explained in terms of the higher electrostatic attraction between the interlayer Lu ions and the tetrahedral 
sheet in tetrahedrally substituted samples than in smectites without this kind of substitution [28], [38] and [39].

In the Ca medium, the $\mathrm{Kd}(\mathrm{La})$ were systematically lower than the $\mathrm{Kd}(\mathrm{Lu})$ for all the clays, with differences up to one order of magnitude. Again, the exception was the MX80 clay, in which differences were only significant at the high concentration range.

The $\mathrm{pH}$ affects lanthanide sorption, since it may induce new sorption sites in clays [27]. However, the $\mathrm{pH}$ was not controlled in these experiments. While the initial $\mathrm{pH}$ in the sorption experiments in the two media differed, the resulting $\mathrm{pH}$ in the final contact solutions was the determined by the equilibrium lanthanide concentration.

\subsection{Evaluation of the lanthanide competitive effect}

A rapid examination of the $\mathrm{Kd}$ data included in Table 3, Table 4, Table 5 and Table 6 seemed to indicate that the competitive effect of the secondary lanthanide was not constant in all the scenarios tested. For a similar change in the concentration of the secondary lanthanide, the changes in the $\mathrm{Kd}$ of the primary lanthanide were higher in the $\mathrm{Ca}$ than in the water medium. Besides, Lu showed a stronger competitive effect (thus provoking a stronger decrease in the $\mathrm{Kd}$ ) than La in the Ca medium. To illustrate these findings, Table 7 shows the changes of the Kd of the primary lanthanide ( $\operatorname{Ln}(1))$ due to the changes in the concentration of the secondary lanthanide (Ln (2)) in various scenarios, expressed as the Kd ratios of the primary lanthanide. The lower the ratio, the lower the influence of the secondary, competitive lanthanide on the $\mathrm{Kd}$ of the primary lanthanide. These ratios show that the competitive effect of the two lanthanides were similar in the water medium, with ratios usually lower than 2 . The only exception was the comparison of the $\mathrm{Kd}$ of the primary lanthanide at a concentration of 3 meq $\mathrm{L}-1$ when increasing the concentration of the secondary lanthanide from 0 to 3 meq L-1 in the HEC smectite. In the Ca medium, the competitive effect of Lu over La was higher than the opposite with many Kd(La) ratios near to or higher than 3 .

Higher ratios (that is, higher Kd decreases) were generally observed at high initial concentrations (i.e., 3 meq $L-1$ ) and in the Ca medium, which are the cases in which the $\mathrm{Kd}$ of the primary lanthanide was already lower. This would indicate that the presence of a competitor would mainly affect the sorption at sites with a low lanthanide affinity, thus provoking a further decrease in the $\mathrm{Kd}$ of the primary lanthanide. Unless the high-affinity sites of the smectites are fully occupied, the role of the competitive element could be weak. When the sorption is governed by low-affinity sites and outer-sphere mechanisms, the presence of the competitor (like the presence of $\mathrm{Ca}$ ) could reduce the sorption of the primary lanthanide.

We completed the examination of the competitive effects with a structural analysis of the residual products of the sorption experiments. Thus, SEM/EDX measurements were carried out to clarify the competitive sorption of lanthanum and lutetium in the scenarios studied. The results for each smectite were similar. As an example we present the EDX spectra of the FEBEX bentonite samples obtained after sorption of La/Lu mixtures at the ratios 0.09/3.1 and 3.1/0.09, in the water and the Ca medium (Fig. 1). The EDX spectra of the initial FEBEX sample (Fig. 1a,(a)) were characterized by the spectral lines $\mathrm{K} \alpha$ of $\mathrm{Mg}, \mathrm{Al}, \mathrm{Si}, \mathrm{K}, \mathrm{Ca}$ and $\mathrm{Fe}$, and $\mathrm{K} \beta$ of $\mathrm{Ca}$ and $\mathrm{Fe}$, which are the constituent elements of its framework. The $\mathrm{Cu} \mathrm{K \alpha}$ line is due to the sample holder. Fig. 
$1 a, b-e$ show new lines due to $L \alpha$ and $L \beta$ of $L a$ and $L u$, with a relative intensity in good agreement with their initial concentration. Besides, Fig. 1a,d-e (samples originated from the sorption at the Ca medium) show a higher intensity line of $\mathrm{Ca}$ which indicates competitive sorption of $\mathrm{Ca}$ when present in the medium. The enlargement of the EDX spectra between 4.0 and $8.5 \mathrm{keV}$ (Fig. 1b) reveals, by comparison with the framework Fe line, that in the Ca medium the sorption of La and Lu decreased, the Ca being preferentially sorbed.

Fig. 2 shows the EDX compositional mapping of the FEBEX bentonite sample after sorption of $\mathrm{La} / \mathrm{Lu}(0.09 / 3.1)$ in the water medium, which allows analysis of the sites governing the sorption of each lanthanide in the mixtures. Whereas the EDX mappings of the Si and Al, which are framework elements, were similar to the SEM image of the lamellar structure, the La and Lu EDX mappings were similar to those of the interlayer cations ( $\mathrm{Na}, \mathrm{Ca}$ and $\mathrm{K}$ ). Therefore, the similar distribution observed for La and Lu confirmed that the sorption of these lanthanides takes place at similar sites.

\subsection{Use of a modified, two-solute Langmuir equation for the fitting of the sorption data}

In order to describe the competitive effect of $L a$ and $L U$ on the lanthanide sorption onto smectites, a three-dimensional, two-solute Langmuir equation was applied to fit the sorption data. Fig. 3 shows an example of the 3-D Langmuir fitting, and Table 8 summarizes all the fitting parameters.

The values of the $b$ parameter, which estimates the maximum sorption capacity, were similar to or slightly higher for Lu than for La in the water medium, but much higher for Lu in the Ca medium. These $b$ values are thus consistent with the $\mathrm{Kd}$ pattern variation observed in the previous section. In the latter case, the sorption isotherms in the Ca medium did not indicate a maximum sorption capacity by the clays, thus the $b$ values overcame the CEC values of the smectite. When performing the Langmuir fitting without the data of the highest initial lanthanide concentration (data not shown), the $b$ values for $L u$ in the Ca medium were closer to or lower than the smectite CEC $(556,1236,925$, and 1347 meq kg-1, for the FEBEX, HEC, MX80, and SCa-3 smectites, respectively).

The $\mathrm{K}$ parameters were higher in the water than in the Ca medium, which was consistent with the higher Kd found in the water medium. The K1 values, generally higher than the K2 in the water medium, also agreed with the low competitive effect observed. Moreover, their values were close to those calculated from single lanthanide solutions [26]. In contrast, the K2(Lu) were similar to or higher than K1(La) in the Ca medium, and much lower than those derived from single lanthanide solutions, thus indicating that $\mathrm{Lu}$ is the stronger competitor in this medium.

\subsection{Lanthanide sorption reversibility}

Table 3, Table 4, Table 5 and Table 6 also list the desorption Kd (Kd,des) and the desorption rate (Rdes) for both lanthanides in the smectitic clays. The two parameters were highly correlated ( $R 2=0.996$ for La and 0.999 for Lu, in all the scenarios tested), thus both predict sorption reversibility, although from two perspectives. In the water medium and from the low values of the Rdes the lanthanide sorption in these smectites was virtually irreversible, and the effect of 
the lanthanide initial concentration and smectite was stronger than the potential effect of the competitive sorption. The results are consistent with previous reports that predict sorption irreversibility due to the strong attraction between trivalent lanthanide cations and clay interlayer exchange sites [23]. However, high Rdes values were observed at the highest concentration of the competitor in the Ca medium, which led to Rdes values lying within the 20$50 \%$ range for La in all cases and within the $5-10 \%$ range for $L u$ in most cases. Therefore, this confirms that the lanthanide sorption in the Ca medium was not only lower, but also more reversible than in the water medium.

The variation pattern of the Kd,des was quite similar to that of the $\mathrm{Kd}$. In general, the $\mathrm{Kd}$, des values increased when the initial target and competitive lanthanide concentration decreased, and were lower in the Ca medium. The $\mathrm{Kd}$,des values were consistently higher than those of $\mathrm{Kd}$, and the two parameters were also highly correlated (Kd, des La $=1.16( \pm 0.02) \mathrm{Kd}, \mathrm{La}+700( \pm 300)$, $\mathrm{R} 2=0.90 ; \mathrm{Kd}$, de $\mathrm{Lu}=1.21( \pm 0.02) \mathrm{Kd}, \mathrm{Lu}+1100( \pm 300), \mathrm{R} 2=0.92)$. This indicated not only that the $\mathrm{Kd}$, des was consistently higher than the $\mathrm{Kd}$, thus confirming the low sorption reversibility, but also that the $\mathrm{Kd}$, des could be predicted from the sorption data.

\section{Conclusions}

When lanthanide sorption is limited by high-affinity sites (thus leading to high Kd values), e.g., when the initial lanthanide concentration in the water medium is low, the competitive effect of lanthanides being sorbed at smectites in binary solutions is weaker than that attributable to lanthanide concentration or smectite type. Moreover, the sites responsible for lanthanide sorption are similar for both lanthanides. Therefore, lanthanide sorption in mixtures can be predicted from data from single solutions. However, the competitive effect occurs when the low-affinity sites govern the lanthanide sorption. This is the case in the experiments in the Ca medium or with high initial lanthanide concentration, as shown here by the major competitive effect of Lu over La. In these cases not only would the sorption be diminished, but the sorption reversibility would also increase. Implications for the management of radioactive waste can easily be deduced, since it is assumed to be a mixture of radionuclides, in the presence of $\mathrm{Ca}$ ions. Although the concentrations of the radioactive leachates from the waste are expected to be lower than the highest values tested here, the role of the cement leachates could decrease the retention capacity of clay engineered barriers.

\section{Acknowledgements}

This research was supported by grants from the Ministry of Education and Science of Spain (Ministerio de Educación y Ciencia de España) for the Project CTM2008-01147/TECNO, from DGICYT for the Project CTQ2007-63297, and from EC for the Project funded within the 6th Framework Programme as the HRM Activity under the Contract MRTN-CT-2006-035957. Besides, the authors would like to thank Dr. A. Padró for his technical help and assistance in the ICP-OES and ICP-MS analyses. SEM-EDX analyses were carried out at the Instituto Ciencia de los Materiales de Sevilla (CICIC). 


\section{References}

[1] C. McCombie, D.L. Pentz, M. Kurzeme, I. Miller

Deep geological repositories: a safe and secure solution to disposal of nuclear wastes

GeoEng2000 - An International Conference on Geotechnical and Geological Engineering, 19-24 November 2000, Melbourne, Australia (2000) Lancaster, PA: Technomic

[2] J. Astudillo Pastor

El Almacenamiento Geológico Profundo de Los Residuos Radiactivos de Alta Actividad

Principios Básicos y Tecnología, ENRESA, Madrid (2001)

[3] N. Chapman

Geological disposal of radioactive waste - concept, status and trends

J. Iber. Geol., 32 (2006), pp. 7-14

[4] A. Meunier, L. Velde, L. Griffault

The reactivity of bentonites: a review. An application to clay barrier stability for nuclear waste storage

Clay Clay Miner., 33 (1998), pp. 187-196

[5] P. Landais

Advances in geochemical research for the underground disposal of high-level, long-lived radioactive waste in a clay formation

J. Geochem. Explor., 88 (2006), pp. 32-36

[6] T. Itakura, D.W. Airey, C.J. Leo, T. Payne, G.D. McOrist

Laboratory studies of the diffusive transport of Cs-137 and Co-60 through potential waste repository soils

J. Environ. Radioact., 101 (2010), pp. 723-729

[7] R. Pusch

Engineered Barriers

V. Popov, R. Pusch (Eds.), Disposal of Hazardous Waste in Underground Mines, Wessex Institute of Technology, UK (2006), pp. 35-40

[8] F. Huertas, L. Griffault, S. Leguey, J. Cuevas, S. Ramírez, R. Vigil de la Villa, J. Cobeña, C. Andrade, M.C. Alonso, A. Hidalgo, J.C. Parneix, F. Rassineux, A. Bouchet, A. Meunier, A. Decarreau, S. Petit, P. Vieillard, Effects of Cement on Clay Barrier Performance, ECOCLAY Project. Tech. Rep. F14W-CT96-0032, European Commission, Brussels, 2000. 
[9] M. Villar, I. Pérez de Villar, P. Martín, M. Pelayo, A. Fernández, A. Garralón, J. Cuevas, S. Leguey, E. Caballero, F. Huertas, C. Jiménez de Cisneros, J. Linares, E. Reyes, A. Delgado, J. Fernández-Soler, J. Astudillo

The study of Spanish clays for their use as sealing materials in nuclear waste repositories: 20 years of progress

J. Iber. Geol., 32 (2006), pp. 15-36

[10] E. Ferrage, C. Tournassat, E. Rinnert, L. Charlet, B. Lanson

Experimental evidence for calcium-chloride ion pairs in the interlayer of montmorillonite. A XRD profile modeling approach

Clay Clay Miner., 53 (2005), pp. 348-360

[11] R.C. Ewing

Nuclear waste forms for actinides

Proc. Natl. Acad. Sci. U.S.A., 96 (1999), pp. 3432-3439

[12] N. Chapman, J. Smellie

Introduction and summary of the workshop: natural analogues to the conditions around a final repository for high-level radioactive waste

Chem. Geol., 55 (1986), pp. 167-173

[13] B. Buil, P. Gomez, A. Garralon, M.J. Turrero

Rare-earth elements: a tool for understanding the behavior of trivalent actinides in the geosphere

Mater. Res. Soc. Symp. Proc., 985 (2007), pp. 437-442

[14] W. Dong, X. Wang, X. Bian, A. Wang, J. Du, Z. Tao

Comparative study on sorption/desorption of radioeuropium on alumina, bentonite and red earth: effects of $\mathrm{pH}$, ionic strength, fulvic acid, and iron oxides in red earth

Appl. Radiat. Isot., 54 (2001), pp. 603-610

[15] R. Kautenburger, H.P. Beck

Influence of geochemical parameters on the sorption and desorption behaviour of europium and gadolinium onto kaolinite

J. Environ. Monit., 12 (2010), pp. 1295-1301

[16] T. Missana, U. Alonso, M. García-Gutierrez, N. Albarran, T. Lopez

Experimental Study and Modeling of Uranium (VI) Sorption onto a Spanish Smectite 
Sci. Basis Nucl. Waste Manag. XXXII, 1124 (2009), pp. 561-566

[17] S. Korichi, A. Bensmaili, M. Keddam

Reactive diffusion of uranium in compacted clay: evaluation of diffusion coefficients by a kinetic approach

Diff. Sol. Liq. V, 297-301 (2010), pp. 275-280

[18] F. Coppin, G. Berger, A. Bauer, S. Castet, M. Loubet

Sorption of lanthanides on smectite and kaolinite

Chem. Geol., 182 (2002), pp. 57-68

[19] M. Bradbury, B. Baeyens

Sorption of Eu on $\mathrm{Na}$ and $\mathrm{Ca}$-montmorillonite: experimental investigations and modelling with cation exchange and surface complexation

Geochim. Cosmochim. Acta, 66 (2002), pp. 2325-2334

[20] E. Tertre, G. Berger, S. Castet, M. Loubet, E. Giffaut

Experimental sorption of $\mathrm{Ni2}+, \mathrm{Cs}+$ and $\mathrm{Ln} 3+$ onto a montmorillonites up to $150^{\circ} \mathrm{C}$

Geochim. Cosmochim. Acta, 69 (2005), pp. 4937-4948

[21] M. Bradbury, B. Baeyens

Modelling the sorption of $\mathrm{Mn}(\mathrm{II}), \mathrm{Co}(\mathrm{II}), \mathrm{Ni}(\mathrm{II}), \mathrm{Cd}(\mathrm{II}), \mathrm{Eu}(\mathrm{III}), \mathrm{Am}(\mathrm{III}), \mathrm{Sn}(\mathrm{IV}), \mathrm{Th}(\mathrm{IV}), \mathrm{Np}(\mathrm{V})$ and $\mathrm{U}(\mathrm{VI})$ on montmorillonites: linear free energy relationships and estimates of surface binding constants for some selected heavy metals and actinides

Geochim. Cosmochim. Acta, 69 (2005), pp. 875-892

[22] D.R. Turner, R.T. Pabalan, F.P. Beretti

Neptunium (V) sorption on montmorillonite: an experimental and surface complexation modeling study

Clay Clay Miner., 46 (1998), pp. 256-259

[23] C. Bonnot-Courtois, N. Jaffrezic-Renault

Étude des échanges entre terres rares et cations interfoliares de deux argiles

Clay Miner., 17 (1982), pp. 409-420

[24] F. Coppin, S. Castet, G. Berger, M. Loubet

Microscopic reversibility of $\mathrm{Sm}$ and $\mathrm{Yb}$ sorption onto smectite and kaolinite: experimental evidence 
Geochim. Cosmochim. Acta, 67 (2003), pp. 2515-2527

[25] E. Galunin, M.D. Alba, M.A. Avilés, M.J. Santos, M. Vidal

Reversibility of La and Lu sorption onto smectites: implications for the design of engineered barriers in deep geological repositories

J. Hazard. Mater., 172 (2009), pp. 1198-1205

[26] E. Galunin, M.D. Alba, M.J. Santos, T. Abrão, M. Vidal

Lanthanide sorption on smectitic clays in presence of cement leachates

Geochim. Cosmochim. Acta, 74 (2010), pp. 862-875

[27] Y. Takahashi, A. Tada, H. Shimizu

Distribution pattern of rare earth ions between water and montmorillonites and its relation to the sorbed species of the ions

Anal. Sci., 20 (2004), pp. 1301-1306

[28] N. Finck, M.L. Schlegel, D. Bosbach

Sites of Lu (III) sorbed to and coprecipitated with hectorite

Environ. Sci. Technol., 43 (2009), pp. 8807-8812

[29] L. Ames, L. Sand, S. Goldich

A contribution on the Hector, California bentonites deposit

Econ. Geol., 53 (1958), pp. 22-37

[30] R. Grim, G. Kulbicky

Montmorillonite: high temperature reactions and classification

Am. Miner., 46 (1961), pp. 1329-1369

[31] A. Fernandez, B. Baeyens, M. Bradbury, P. Rivas

Analysis of the porewater chemical composition of a Spanish compacted bentonite used in an engineered barrier

Phys. Chem. Earth, 29 (2004), pp. 105-118

[32] G. Montes-H, B. Fritz, A. Clement, N. Michau

Modelling of geochemical reactions and experimental cation exchange in MX-80 bentonite

J. Environ. Manage., 77 (2007), pp. 35-46

[33] D. Do 
Adsorption Analysis: Equilibria and Kinetics, vol. 2 Imperial College Press-ICP, London (1998)

[34] V.C. Srivastava, I.D. Mall, Mishra

Equilibrium modelling of single and binary adsorption of cadmium and nickel onto bagasse fly ash

Chem. Eng. J., 117 (2006), pp. 79-91

[35] S. Oh, M.Y. Kwak, W.S. Shin

Competitive sorption of lead and cadmium onto sediments

Chem. Eng. J., 152 (2009), pp. 376-388

[36] C. Yan, G. Li, P. Xue, Q. Wei, Q. Li

Competitive effect of $\mathrm{Cu}(\mathrm{II})$ and $\mathrm{Zn}$ (II) on the biosorption of lead(II) by Myriophyllum spicatum

J. Hazard. Mater., 179 (2010), pp. 721-728

[37] The Mathworks Inc., User Guide - Matlab 7.10.0 (R2010a), Apple Hill Drive, Natick, MA 01760-2098, USA, 2010.

[38] G. Sposito, R. Prost

Structure of water adsorbed on smectites

Chem. Rev., 82 (1982), pp. 553-573

[39] B.J. Teppen, D.M. Miller

Hydration energy determines isovalent cation exchange selectivity by clay minerals

Soil Sci. Soc. Am. J., 70 (2006), pp. 31-40 


\section{Figure captions}

Figure 1. (a) EDX spectra of the FEBEX smectite: a) initial sample, b) after sorption of La/Lu $(0.09 / 3.1)$ in the water medium, c) after sorption of La/Lu (3.1/0.09) in the water medium, d) after sorption of $\mathrm{La} / \mathrm{Lu}(0.09 / 3.1)$ in the Ca medium and e) after sorption of $\mathrm{La} / \mathrm{Lu}(3.1 / 0.09)$ in the Ca medium. (b) Enlargement of the EDX spectra of the FEBEX smectite in the 4-8.5 keV range: a) after sorption of $\mathrm{La} / \mathrm{Lu}(0.09 / 3.1)$ in the water medium, b) after sorption of $\mathrm{La} / \mathrm{Lu}$ (3.1/0.09) in the water medium, c) after sorption of La/Lu (0.09/3.1) in the Ca medium and d) after sorption of La/Lu (3.1/0.09) in the Ca medium.

Figure 2. SEM micrograph and EDX mapping of the FEBEX smectite after sorption of La/Lu $(0.09 / 3.1)$ in the water medium. The scale mark in the EDX mappings indicates $1 \mu \mathrm{m}$.

Figure 3. Fitting of the sorption data with the three-dimensional, two-solute Langmuir equation. Case of the HEC smectite. Prediction of the Csorb,La (a) and Csorb,Lu (b) in the water medium, and of the Csorb,La (c) and Csorb,Lu (d) in the Ca medium. 
Table 1. Characteristics of smectitic clays selected for sorption experiments.

\begin{tabular}{|c|c|c|c|c|c|c|}
\hline Clay & Structural formula & Geometry & \begin{tabular}{|l|} 
Isomorphic \\
Substitutions
\end{tabular} & $\begin{array}{l}\text { Total } \\
\text { charge/u.c. }\end{array}$ & CEC meq kg-1e & pH \\
\hline $\mathrm{FEBEX}^{\mathrm{a}}$ & 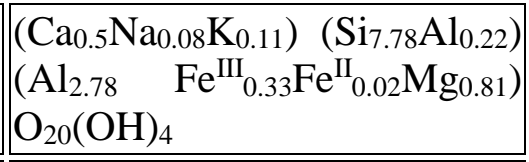 & Dioctahedral & $\begin{array}{l}\text { Tetrahedral and } \\
\text { octahedral sheets }\end{array}$ & 1.19 & 1582 & 9.6 \\
\hline $\mathrm{HEC}^{\mathrm{b}}$ & $\begin{array}{l}\mathrm{Ca}_{0.33}\left(\mathrm{Si}_{7.96} \mathrm{Al}_{0.04}\right) \\
\left(\mathrm{Mg}_{5.3} \mathrm{Al}_{0.04} \mathrm{Li}_{0.66}\right) \mathrm{O}_{20}(\mathrm{OH})_{4}\end{array}$ & Trioctahedral & Octahedral sheet & 0.66 & 871 & $\mid 10.4$ \\
\hline MX80 & \begin{tabular}{|ll}
$\left(\mathrm{Na}_{0.36} \mathrm{Ca}_{0.20}\right)$ & $\left(\mathrm{Si}_{7.96} \mathrm{Al}_{0.04}\right)$ \\
$\left(\mathrm{Al}_{3.1} \mathrm{Mg}_{0.56} \mathrm{Fe}^{\mathrm{III}}\right.$ & ${ }_{0.18} \mathrm{Fe}^{\mathrm{II}}$ \\
$\left.\mathrm{O}_{20.16}\right)$
\end{tabular} & Dioctahedral & Octahedral sheet & 0.76 & 1021 & |7.6 \\
\hline $\mathrm{SCa}-3^{\mathrm{d}}$ & $\begin{array}{l}\left(\mathrm{Mg}_{0.45} \mathrm{Ca}_{0.15} \mathrm{Na}_{0.26} \mathrm{~K}_{0.01}\right) \\
\left\{\mathrm{Si}_{7.81} \mathrm{Al}_{0.19}\right\} \\
\left\{\mathrm{Al}_{2.55} \mathrm{Mg}_{1.31} \mathrm{Fe}_{0.12} \mathrm{Ti}_{0.02}\right\} \\
\mathrm{O}_{20}(\mathrm{OH})_{4} \\
\end{array}$ & Dioctahedral & $\begin{array}{l}\text { Tetrahedral and } \\
\text { octahedral sheets }\end{array}$ & 1.47 & 1979 & |9.0 \\
\hline
\end{tabular}

a Bentonite FEBEX (ENRESA, Spain).

b Hectorite (Source Clays Repository of the Clay Minerals Society, University of Missouri, Columbia, USA).

c Bentonite MX80 (CIEMAT, Spain).

d Otay montmorillonite (Solvay Alkali GMBH).

e Theoretical cation exchange capacity value, mathematically deduced from clay molecular formula. 
Table 2

Table 2. Experimental design: theoretical initial $\mathrm{La}$ and $\mathrm{Lu}$ concentrations $\left(C_{\mathrm{init}, \mathrm{La}}\right.$, $C_{\text {init,Lu}}$; meq $\mathrm{L}^{-1}$ ) in the mixture solutions.

\begin{tabular}{|l||l|l|l|}
\hline \multicolumn{2}{|l|}{ La sorption isotherms } & \multicolumn{2}{l|}{ Lu sorption isotherms } \\
\hline \hline $\boldsymbol{C}_{\text {init,La }}$ & $\boldsymbol{C}_{\text {init,Lu }}$ & $\boldsymbol{C}_{\text {init,Lu }}$ & $\boldsymbol{C}_{\text {init,La }}$ \\
\hline 0 & 0.03 & 0 & 0.03 \\
\hline 0 & 0.03 & 0.01 & 0.03 \\
\hline 0.01 & 0.03 & 0.03 & 0.03 \\
\hline 0.03 & 0.03 & 0.09 & 0.03 \\
\hline 0.09 & 0.03 & 1 & 0.03 \\
\hline \hline 1 & 3 & 0 & 3 \\
\hline 0 & 3 & 0.09 & 3 \\
\hline 0.09 & 3 & 1 & 3 \\
\hline 1 & 3 & 3 & 3 \\
\hline 3 & 3 & 9 & 3 \\
\hline 9 & & & \\
\hline
\end{tabular}


Table 3

Table 3. Sorption-desorption parameters for both lanthanides in the tested clays in the water medium $\left(C_{\text {init }}\right.$, meq L ${ }^{-1} ; C_{\text {sorb }}$, meq kg-1 $K_{\mathrm{d}}(\mathrm{SD}), K_{\mathrm{d}, \mathrm{des}}(\mathrm{SD}), \mathrm{L} \mathrm{kg}^{-1}$; $\left.R_{\text {des }}(\mathrm{SD}), \%\right)$.

\begin{tabular}{|c|c|c|c|c|c|c|c|c|c|c|c|}
\hline \multirow{2}{*}{ Clay } & \multirow{2}{*}{ pH } & \multirow{2}{*}{$\begin{array}{l}\begin{array}{l}\text { Cinit } \\
\text { (La) }\end{array} \\
\end{array}$} & \multirow{2}{*}{$\begin{array}{l}C_{\text {init }} \\
(\mathbf{L u})\end{array}$} & \multirow{2}{*}{\begin{tabular}{|l}
$C_{\text {sorb }}$ \\
$(\mathbf{L a})$
\end{tabular}} & \multirow{2}{*}{\begin{tabular}{|l|}
$C_{\text {sorb }}$ \\
$(\mathbf{L u})$
\end{tabular}} & \multicolumn{3}{|l|}{ La } & \multicolumn{3}{|l|}{ Lu } \\
\hline & & & & & & $K_{d}$ & $K_{\mathrm{d}, \mathrm{des}}$ & $\boldsymbol{R}_{\text {des }}$ & $K_{\mathrm{d}}$ & $K_{\mathrm{d}, \mathrm{des}}$ & $R_{\text {des }}$ \\
\hline \multirow{10}{*}{ FEBEX } & 9.0 & || 0 & 0.03 & ||- & 4.8 & ||- & $\mid$ & |- & $\begin{array}{l}32,900 \\
(1400)\end{array}$ & $35,100(300)$ & $0.5(0.1)$ \\
\hline & 9.7 & $\mid 0.01$ & 0.03 & $\mid 1.4$ & 4.9 & $\begin{array}{l}63,400 \\
(1300)\end{array}$ & $\begin{array}{l}64,200 \\
(900)\end{array}$ & $\begin{array}{l}0.2 \\
(0.1)\end{array}$ & $\begin{array}{l}33,800 \\
(2100)\end{array}$ & $44,900(5500)$ & $0.3(0.1)$ \\
\hline & 9.7 & 0.03 & 0.03 & 4.5 & $\mid 4.7$ & $\begin{array}{l}28,000 \\
(2700)\end{array}$ & $\begin{array}{l}30,400 \\
(450)\end{array}$ & $\begin{array}{l}0.5 \\
(0.1)\end{array}$ & $\begin{array}{l}32,700 \\
(2800)\end{array}$ & $41,100(7700)$ & $0.4(0.1)$ \\
\hline & 9.5 & $\mid 0.09$ & 0.03 & || 14 & 4.9 & $\begin{array}{l}26,100 \\
(1500)\end{array}$ & $\begin{array}{l}27,000 \\
(600)\end{array}$ & $\begin{array}{l}0.6 \\
(0.1)\end{array}$ & $\begin{array}{l}26,000 \\
(3400)\end{array}$ & $29,200(4300)$ & $0.5(0.1)$ \\
\hline & 8.7 & $\mid 1.01$ & 0.04 & $\mid 150$ & $\mid 5.4$ & \begin{tabular}{|l}
23,200 \\
$(600)$
\end{tabular} & $\begin{array}{l}26,500 \\
(1100)\end{array}$ & $\begin{array}{l}0.6 \\
(0.1)\end{array}$ & $\begin{array}{l}22,600 \\
(2200)\end{array}$ & $26,700(2900)$ & $0.5(0.1)$ \\
\hline & 6.5 & $\mid 0$ & 3.03 & ||- & 450 & ||- & $\mid$ & |- & $\begin{array}{l}15,900 \\
(1600)\end{array}$ & $20,400(260)$ & $0.8(0.1)$ \\
\hline & 6.7 & 0.10 & 3.06 & || 14 & 450 & $\begin{array}{l}16,100 \\
(1100)\end{array}$ & $\begin{array}{l}19,500 \\
(2200)\end{array}$ & $\begin{array}{l}0.8 \\
(0.1)\end{array}$ & $\begin{array}{l}14,100 \\
(1300)\end{array}$ & $15,800(720)$ & $1.0(0.1)$ \\
\hline & 6.7 & $\mid 1.20$ & 3.15 & $\mid 180$ & 460 & $\mid \begin{array}{l}14,900 \\
(1200)\end{array}$ & $\begin{array}{l}15,400 \\
550)\end{array}$ & $\left(\begin{array}{l}1.0 \\
(0.2)\end{array}\right.$ & $\begin{array}{l}13,000 \\
(520)\end{array}$ & $14,300(380)$ & || $1.1(0.1)$ \\
\hline & 6.1 & $\mid 3.13$ & 3.15 & 470 & $\mid 470$ & $\begin{array}{l}11,700 \\
(340)\end{array}$ & $\begin{array}{l}12,900 \\
(290)\end{array}$ & $\begin{array}{l}1.2 \\
(0.1)\end{array}$ & $\begin{array}{l}12,700 \\
540)\end{array}$ & $13,900(330)$ & $\mid 1.1(0.1)$ \\
\hline & 6.0 & $\mid$ | 9.17 & 3.19 & 850 & $\mid 300$ & $\begin{array}{l}240 \\
(20)\end{array}$ & {$\left[\begin{array}{l}11,300 \\
(240)\end{array}\right.$} & $\begin{array}{l}1.3 \\
(0.1) \\
\end{array}$ & $250(10)$ & |6200(70) & $2.4(0.1)$ \\
\hline \multirow{7}{*}{ HEC } & 10.1 & || 0 & 0.03 & ||- & 4.8 & ||- & $\mid$ & |- & $\begin{array}{l}16,300 \\
(2400)\end{array}$ & $53,000(5700)$ & $0.3(0.1)$ \\
\hline & 10.4 & $\mid 0.01$ & 0.03 & $\mid 1.4$ & 4.9 & \begin{tabular}{|l}
31,700 \\
$(670)$
\end{tabular} & $\begin{array}{l}59,300 \\
(8000)\end{array}$ & $\begin{array}{l}0.3 \\
(0.1)\end{array}$ & $\begin{array}{l}14,000 \\
(1800)\end{array}$ & $20,000(1100)$ & $0.8(0.1)$ \\
\hline & 10.4 & 0.03 & 0.03 & $\mid 4.6$ & 4.8 & $\begin{array}{l}28,400 \\
(2600)\end{array}$ & $\begin{array}{l}33,700 \\
(4100)\end{array}$ & $\begin{array}{l}0.5 \\
(0.1) \\
\end{array}$ & $\begin{array}{l}13,700 \\
(1900)\end{array}$ & $16,300(870)$ & $1.0(0.1)$ \\
\hline & 10.3 & $\mid 0.09$ & 0.03 & || 14 & 4.9 & $\begin{array}{l}28,100 \\
(1900) \\
\end{array}$ & $\begin{array}{l}35,800 \\
(2300)\end{array}$ & $\begin{array}{l}0.4 \\
(0.1) \\
\end{array}$ & $\begin{array}{l}12,400 \\
(450)\end{array}$ & $15,300(170)$ & $1.0(0.1)$ \\
\hline & 9.8 & $\mid 1.01$ & 0.04 & $\mid 150$ & $\mid 5.4$ & $\mid \begin{array}{l}22,100 \\
(3200)\end{array}$ & $\left(\begin{array}{l}23,700 \\
(3300)\end{array}\right.$ & $\begin{array}{l}0.7 \\
(0.1)\end{array}$ & $\begin{array}{l}12,100 \\
80)\end{array}$ & $14,500(180)$ & || $1.1(0.1)$ \\
\hline & 7.1 & || 0 & 3.03 & ||- & 450 & ||- & ||- & |- & $\begin{array}{l}10,000 \\
(1100)\end{array}$ & $16,300(480)$ & $1.0(0.1)$ \\
\hline & 7.4 & 0.10 & 3.06 & || 14 & 450 & $\begin{array}{l}14,500 \\
(1500)\end{array}$ & $\begin{array}{l}18,800 \\
(1600)\end{array}$ & $\begin{array}{l}0.8 \\
(0.1) \\
\end{array}$ & $\begin{array}{l}7300 \\
(510)\end{array}$ & $9300(120)$ & $1.6(0.1)$ \\
\hline
\end{tabular}




\begin{tabular}{|c|c|c|c|c|c|c|c|c|c|c|c|}
\hline \multirow{2}{*}{ Clay } & \multirow{2}{*}{ pH } & \multirow{2}{*}{$\begin{array}{l}C_{\text {init }} \\
\text { (La) }\end{array}$} & \multirow{2}{*}{$\begin{array}{l}C_{\text {init }} \\
(\mathbf{L u})\end{array}$} & \multirow{2}{*}{$\begin{array}{l}C_{\text {sorb }} \\
\text { (La) }\end{array}$} & \multirow{2}{*}{\begin{tabular}{|l|}
$C_{\text {sorb }}$ \\
$(\mathrm{Lu})$
\end{tabular}} & \multicolumn{3}{|l|}{$\mathbf{L a}$} & \multicolumn{3}{|l|}{$\mathrm{Lu}$} \\
\hline & & & & & & $K_{d}$ & $K_{\mathrm{d}, \mathrm{des}}$ & $\boldsymbol{R}_{\text {des }}$ & $K_{d}$ & $K_{\mathrm{d}, \mathrm{des}}$ & $R_{\mathrm{des}}$ \\
\hline & 7.1 & $\mid 1.20$ & 3.15 & $\mid 170$ & 450 & \begin{tabular}{|l|}
13,800 \\
$(1300)$ \\
\end{tabular} & $\begin{array}{l}14,900 \\
(850)\end{array}$ & $\begin{array}{l}1.0 \\
(0.1)\end{array}$ & $\begin{array}{l}5500 \\
(180)\end{array}$ & ||7800 (90) & $\mid 1.9(0.1)$ \\
\hline & 6.7 & $\mid 3.13$ & 3.15 & $\mid 440$ & |460 & $\mid \begin{array}{l}1200 \\
50)\end{array}$ & $\begin{array}{l}8800 \\
(440)\end{array}$ & $\begin{array}{l}1.8 \\
(0.1)\end{array}$ & $\begin{array}{l}1500 \\
50)\end{array}$ & ||6700(90) & | $2.3(0.1)$ \\
\hline & 6.4 & $\mid 9.17$ & 3.19 & $\mid 600$ & $\mid 310$ & $\begin{array}{l}120 \\
(1)\end{array}$ & $\begin{array}{l}3400 \\
(280)\end{array}$ & $\begin{array}{l}4.2 \\
(0.4)\end{array}$ & $\mid 274(0)$ & $3500(100)$ & $4.2(0.2)$ \\
\hline \multirow{10}{*}{ MX80 } & 9.9 & | 0 & 0.03 & |- & 4.7 & |- & ||$-$ & |- & $\begin{array}{l}4400 \\
(350)\end{array}$ & $6800(1300)$ & $\mid 2.4(0.4)$ \\
\hline & 9.9 & $\mid 0.01$ & 0.03 & $\mid 1.3$ & $\mid 4.7$ & $\begin{array}{l}8300 \\
(820)\end{array}$ & $\begin{array}{l}10,600 \\
(70)\end{array}$ & $\begin{array}{l}1.5 \\
(0.1)\end{array}$ & $\begin{array}{l}5000 \\
(390)\end{array}$ & $5700(570)$ & || $2.7(0.3)$ \\
\hline & 9.9 & $\mid 0.03$ & 0.03 & $\mid 4.4$ & 4.5 & $\begin{array}{l}6500 \\
(760)\end{array}$ & $\begin{array}{l}7600 \\
(630)\end{array}$ & $\begin{array}{l}2.0 \\
(0.2)\end{array}$ & $\begin{array}{l}4300 \\
(250)\end{array}$ & $5300(460)$ & $\mid 2.9(0.2)$ \\
\hline & 9.9 & 0.09 & 0.03 & $\mid 14$ & 4.7 & \begin{tabular}{|l|}
5000 \\
$(1400)$
\end{tabular} & $\begin{array}{l}6300 \\
(1600)\end{array}$ & $\begin{array}{l}2.5 \\
(0.5) \\
\end{array}$ & $4100(5)$ & $5000(30)$ & $\mid 3.0(0.1)$ \\
\hline & 9.0 & $\mid 1.01$ & 0.04 & $\mid 150$ & $\mid 5.4$ & $\begin{array}{l}2800 \\
(210)\end{array}$ & $\begin{array}{l}3500 \\
(220)\end{array}$ & $\begin{array}{l}4.3 \\
(0.1) \\
\end{array}$ & $\begin{array}{l}3900 \\
(170)\end{array}$ & $4200(190)$ & $\mid 3.6(0.3)$ \\
\hline & 7.2 & | 0 & 3.03 & |- & |440 & |- & $\mid-$ & |- & $\begin{array}{l}3100 \\
(140)\end{array}$ & $4000(550)$ & $\mid 3.9(0.5)$ \\
\hline & 7.5 & 0.10 & 3.06 & $\mid 14$ & 460 & $\begin{array}{l}3300 \\
(220)\end{array}$ & $\left(\begin{array}{l}4000 \\
(560)\end{array}\right.$ & $\begin{array}{l}3.9 \\
(0.5)\end{array}$ & |5900 (8) & $7200(120)$ & || $2.1(0.1)$ \\
\hline & 7.2 & $\mid 1.20$ & 3.15 & $\mid 170$ & 460 & $\begin{array}{l}2900 \\
(130)\end{array}$ & $\begin{array}{l}3700 \\
(240)\end{array}$ & $\begin{array}{l}4.0 \\
(0.2) \\
\end{array}$ & $\begin{array}{l}4100 \\
(330)\end{array}$ & $4700(160)$ & $\mid 3.2(0.1)$ \\
\hline & 6.7 & $\mid 3.13$ & 3.15 & $\mid 440$ & 440 & $\begin{array}{l}2900 \\
(130)\end{array}$ & $\begin{array}{l}3600 \\
(280)\end{array}$ & $\begin{array}{l}4.0 \\
(0.3) \\
\end{array}$ & $\begin{array}{l}2200 \\
(60)\end{array}$ & || $2700(80)$ & || $5.2(0.1)$ \\
\hline & 6.3 & $\mid 9.17$ & 3.19 & ||700 & |270 & $\begin{array}{l}160 \\
(4)\end{array}$ & $\begin{array}{l}2700 \\
(500)\end{array}$ & $\begin{array}{l}5.2 \\
(0.9) \\
\end{array}$ & $\mid 210(7)$ & $1800(110)$ & $\mid 7.7(0.5)$ \\
\hline \multirow{7}{*}{ SCa-3 } & 8.9 & | 0 & 0.03 & |- & 4.6 & |- & $\mid-$ & |- & $\begin{array}{l}48,500 \\
(5500)\end{array}$ & $49,900(6200)$ & $\mid 0.3(0.1)$ \\
\hline & 9.1 & $\mid 0.01$ & 0.03 & $\mid 1.4$ & $\mid 4.9$ & \begin{tabular}{|l|}
23,100 \\
$(5300)$ \\
\end{tabular} & $\begin{array}{l}57,300 \\
(11,700) \\
\end{array}$ & $\begin{array}{l}0.3 \\
(0.1) \\
\end{array}$ & \begin{tabular}{|l}
44,500 \\
$(6000)$ \\
\end{tabular} & 73,500 (1300) & $0.2(0.1)$ \\
\hline & 9.2 & $\mid 0.03$ & 0.03 & 4.7 & 4.9 & $\begin{array}{l}22,800 \\
(2900) \\
\end{array}$ & $\begin{array}{l}24,800 \\
(2100)\end{array}$ & $\begin{array}{l}0.6 \\
(0.1) \\
\end{array}$ & $\begin{array}{l}30,200 \\
(3900) \\
\end{array}$ & $39,900(4)$ & $\mid 0.4(0.1)$ \\
\hline & 9.0 & $\mid 0.09$ & 0.03 & $\mid 14$ & 4.8 & \begin{tabular}{|l|}
21,700 \\
$(1400)$ \\
\end{tabular} & $\begin{array}{l}24,400 \\
(1600)\end{array}$ & $\begin{array}{l}0.6 \\
(0.1) \\
\end{array}$ & $\begin{array}{l}28,200 \\
(4300) \\
\end{array}$ & $27,900(2300)$ & | $0.6(0.1)$ \\
\hline & 7.7 & $\mid 1.01$ & 0.04 & $\mid 150$ & $\mid 5.3$ & \begin{tabular}{|l|}
21,200 \\
$(2000)$ \\
\end{tabular} & $\begin{array}{l}23,400 \\
(1800)\end{array}$ & $\begin{array}{l}0.7 \\
(0.1) \\
\end{array}$ & $\begin{array}{l}17,200 \\
(1500) \\
\end{array}$ & $20,600(3000)$ & $\mid 0.8(0.1)$ \\
\hline & 6.5 & | 0 & 3.03 & |- & $\mid 450$ & |- & ||$-$ & |- & $\begin{array}{l}27,000 \\
(2000)\end{array}$ & $28,700(480)$ & | $0.6(0.1)$ \\
\hline & 6.6 & 0.10 & 3.06 & $\mid 14$ & $\mid 460$ & \begin{tabular}{|l|}
18,200 \\
$(1700)$
\end{tabular} & $\begin{array}{l}20,600 \\
(2500)\end{array}$ & $\begin{array}{l}0.7 \\
(0.1) \\
\end{array}$ & $\begin{array}{l}26,400 \\
(3100) \\
\end{array}$ & $29,700(2400)$ & $\mid 0.5(0.1)$ \\
\hline
\end{tabular}




\begin{tabular}{|c|c|c|c|c|c|c|c|c|c|c|c|}
\hline \multirow{2}{*}{ Clay } & \multirow{2}{*}{ pH } & \multirow{2}{*}{$\begin{array}{l}C_{\text {init }} \\
\text { (La) }\end{array}$} & \multirow{2}{*}{$\begin{array}{l}C_{\text {init }} \\
(\mathbf{L u})\end{array}$} & \multirow{2}{*}{\begin{tabular}{|l|}
$C_{\text {sorb }}$ \\
$(\mathbf{L a})$ \\
\end{tabular}} & \multirow{2}{*}{\begin{tabular}{|l|}
$C_{\text {sorb }}$ \\
$(\mathrm{Lu})$
\end{tabular}} & \multicolumn{3}{|l|}{ La } & \multicolumn{3}{|l|}{$\mathbf{L u}$} \\
\hline & & & & & & $K_{d}$ & $K_{\mathrm{d}, \mathrm{des}}$ & $\boldsymbol{R}_{\text {des }}$ & $K_{d}$ & $K_{d, d e s}$ & $\boldsymbol{R}_{\text {des }}$ \\
\hline & 7.1 & $\mid 1.20$ & 3.15 & $\mid 180$ & 470 & \begin{tabular}{|l}
16,800 \\
$(960)$
\end{tabular} & $\begin{array}{l}20,000 \\
(820)\end{array}$ & \begin{tabular}{|l|}
$\begin{array}{l}0.8 \\
(0.1)\end{array}$ \\
\end{tabular} & $\begin{array}{l}21,400 \\
(960)\end{array}$ & $25,900(1400)$ & $0.6(0.1)$ \\
\hline & 6.5 & $\mid 3.13$ & 3.15 & 470 & 470 & $\begin{array}{l}12,000 \\
(190)\end{array}$ & $\begin{array}{l}13,800 \\
(210)\end{array}$ & $\begin{array}{l}1.1 \\
(0.1)\end{array}$ & $\begin{array}{l}10,700 \\
(920)\end{array}$ & $12,600(380)$ & $\mid 1.2(0.1)$ \\
\hline & 6.0 & || 9.17 & 3.19 & $\mid 1000$ & $\mid 370$ & $\begin{array}{l}450 \\
(20)\end{array}$ & $\begin{array}{l}4100 \\
60)\end{array}$ & $\begin{array}{l}3.5 \\
(0.1)\end{array}$ & |530 (20) & $2500(210)$ & $\mid 5.6$ \\
\hline
\end{tabular}


Table 4. Sorption-desorption parameters for both lanthanides in the tested clays in the water medium $\left(C_{\text {init }}\right.$, meq L ${ }^{-1} ; C_{\text {sorb }}$, meq kg ${ }^{-1} ; K_{\mathrm{d}}(\mathrm{SD}), K_{\mathrm{d}, \mathrm{des}}(\mathrm{SD}), \mathrm{L} \mathrm{kg}^{-1}$; $\left.R_{\text {des }}(\mathrm{SD}), \%\right)$.

\begin{tabular}{|c|c|c|c|c|c|c|c|c|c|c|c|}
\hline \multirow{2}{*}{ Clay } & \multirow{2}{*}{ pH } & \multirow{2}{*}{$\begin{array}{l}C_{\text {init }} \\
(\mathbf{L u})\end{array}$} & \multirow{2}{*}{$\begin{array}{l}\text { Cinit } \\
\text { (La) }\end{array}$} & \multirow{2}{*}{$\begin{array}{l}C_{\text {sorb }} \\
(\mathrm{Lu})\end{array}$} & \multirow{2}{*}{$\begin{array}{l}C_{\text {sorb }} \\
(\mathbf{L a}) \\
\end{array}$} & \multicolumn{3}{|l|}{ Lu } & \multicolumn{3}{|l|}{ La } \\
\hline & & & & & & $K_{d}$ & $K_{\mathrm{d}, \mathrm{des}}$ & $R_{\text {des }}$ & $K_{\mathrm{d}}$ & $K_{\mathrm{d}, \mathrm{des}}$ & $R_{\mathrm{des}}$ \\
\hline \multirow{10}{*}{ FEBEX } & 9.2 & 0 & 0.03 & |- & 4.6 & |- & ||- & |- & $\begin{array}{l}23,800 \\
(3100)\end{array}$ & $\begin{array}{l}44,900 \\
(490)\end{array}$ & $\begin{array}{l}0.4 \\
(0.1)\end{array}$ \\
\hline & 9.9 & | 0.01 & 0.03 & $\mid 1.5$ & 4.3 & $43,000(780)$ & $\begin{array}{l}43,800 \\
(760)\end{array}$ & \begin{tabular}{|l|}
0.3 \\
$(0.1)$ \\
\end{tabular} & \begin{tabular}{|l}
28,500 \\
$(500)$
\end{tabular} & \begin{tabular}{|l}
33,900 \\
$(590)$
\end{tabular} & $\begin{array}{l}0.4 \\
(0.1) \\
\end{array}$ \\
\hline & 9.7 & 0.03 & 0.03 & $\mid 4.7$ & 4.5 & \begin{tabular}{|l}
32,700 \\
$(2800)$
\end{tabular} & $\begin{array}{l}41,100 \\
(7700)\end{array}$ & \begin{tabular}{|l|}
0.4 \\
$(0.1)$ \\
\end{tabular} & $\begin{array}{l}28,000 \\
(2700)\end{array}$ & \begin{tabular}{|l}
30,400 \\
$(450)$
\end{tabular} & $\begin{array}{l}0.5 \\
(0.1) \\
\end{array}$ \\
\hline & 9.7 & 0.09 & 0.03 & $\mid 14$ & 4.5 & \begin{tabular}{|l|}
25,700 \\
$(3900)$
\end{tabular} & $\begin{array}{l}27,900 \\
(3100)\end{array}$ & \begin{tabular}{|l|}
0.5 \\
$(0.1)$ \\
\end{tabular} & \begin{tabular}{|l}
14,400 \\
$(810)$
\end{tabular} & $\begin{array}{l}16,400 \\
(1600)\end{array}$ & $\begin{array}{l}0.9 \\
(0.1) \\
\end{array}$ \\
\hline & 7.4 & $\mid 1.15$ & 0.03 & $\mid 170$ & 5.0 & $\begin{array}{l}15,400 \\
(3900)\end{array}$ & $\begin{array}{l}16,900 \\
(500)\end{array}$ & $\begin{array}{l}0.9 \\
(0.1) \\
\end{array}$ & $\begin{array}{l}8100 \\
(650)\end{array}$ & $\begin{array}{l}10,900 \\
(1100)\end{array}$ & $\begin{array}{l}1.4 \\
(0.1) \\
\end{array}$ \\
\hline & 6.6 & $\|$ & 3.29 & ||- & 490 & - & $\mid$ & |- & \begin{tabular}{|l}
15,100 \\
$550)$
\end{tabular} & $\begin{array}{l}24,600 \\
(1500)\end{array}$ & $\begin{array}{l}0.6 \\
(0.1) \\
\end{array}$ \\
\hline & 7.1 & 0.09 & 3.10 & $\mid 14$ & 470 & $13,600(2000)$ & $\begin{array}{l}15,500 \\
(2500)\end{array}$ & $\begin{array}{l}1.0 \\
(0.2)\end{array}$ & $\begin{array}{l}22,000 \\
(1600)\end{array}$ & $\begin{array}{l}23,900 \\
(1700)\end{array}$ & $\begin{array}{l}0.6 \\
(0.1)\end{array}$ \\
\hline & 6.7 & $\mid 1.08$ & 3.13 & 160 & 470 & $13,600(680)$ & $\begin{array}{l}15,300 \\
(580)\end{array}$ & $\mid \begin{array}{l}1.0 \\
(0.1)\end{array}$ & $\begin{array}{l}15,700 \\
(930)\end{array}$ & $\begin{array}{l}18,300 \\
(970)\end{array}$ & $\begin{array}{l}0.8 \\
(0.1)\end{array}$ \\
\hline & 6.1 & $\mid 3.15$ & 3.13 & 470 & 470 & $12,700(540)$ & \begin{tabular}{|l}
13,900 \\
$(330)$
\end{tabular} & \begin{tabular}{|l|}
1.1 \\
$(0.1)$ \\
\end{tabular} & \begin{tabular}{|l}
11,700 \\
$(340)$
\end{tabular} & $\begin{array}{l}12,900 \\
(290)\end{array}$ & $\begin{array}{l}1.2 \\
(0.1)\end{array}$ \\
\hline & 6.0 & $\mid 9.12$ & 3.10 & 820 & 290 & $220(10)$ & 9800 (480) & \begin{tabular}{|l|}
1.5 \\
$(0.1)$ \\
\end{tabular} & $240(20)$ & $\begin{array}{l}5200 \\
(610)\end{array}$ & $\begin{array}{l}2.9 \\
(0.4) \\
\end{array}$ \\
\hline \multirow{7}{*}{ HEC } & 10.2 & || 0 & 0.03 & |- & 4.6 & - & - & $\mid-$ & $\begin{array}{l}50,100 \\
(5700)\end{array}$ & \begin{tabular}{|l}
114,000 \\
$(2500)$
\end{tabular} & $\begin{array}{l}0.2 \\
(0.1)\end{array}$ \\
\hline & 10.4 & $\mid 0.01$ & 0.03 & $\mid 1.5$ & 4.3 & $14,700(3600)$ & $\begin{array}{l}29,500 \\
(610)\end{array}$ & \begin{tabular}{|l|}
0.5 \\
$(0.1)$ \\
\end{tabular} & $\begin{array}{l}31,000 \\
(3700)\end{array}$ & $\begin{array}{l}34,500 \\
(640)\end{array}$ & $\begin{array}{l}0.4 \\
(0.1)\end{array}$ \\
\hline & 10.4 & $\mid 0.03$ & 0.03 & || 4.8 & 4.6 & $13,700(1900)$ & $\begin{array}{l}16,300 \\
(870)\end{array}$ & \begin{tabular}{|l|}
1.0 \\
$(0.1)$ \\
\end{tabular} & $\begin{array}{l}28,400 \\
(2600)\end{array}$ & $\begin{array}{l}33,700 \\
(4100)\end{array}$ & $\begin{array}{l}0.5 \\
(0.1)\end{array}$ \\
\hline & 10.4 & 0.09 & 0.03 & $\mid 14$ & 4.6 & $12,600(810)$ & $\begin{array}{l}15,200 \\
(1100)\end{array}$ & \begin{tabular}{|l|}
1.1 \\
$(0.1)$ \\
\end{tabular} & $\begin{array}{l}24,200 \\
(3800)\end{array}$ & $\begin{array}{l}26,600 \\
(2000)\end{array}$ & $\begin{array}{l}0.6 \\
(0.1)\end{array}$ \\
\hline & 9.6 & $\mid 1.15$ & 0.03 & $\mid 170$ & 4.8 & $5100(290)$ & 4600 (390) & \begin{tabular}{|l|}
3.2 \\
$(0.3)$
\end{tabular} & $\begin{array}{l}2900 \\
(330)\end{array}$ & $\begin{array}{l}3100 \\
(380)\end{array}$ & $\begin{array}{l}4.8 \\
(0.6)\end{array}$ \\
\hline & 8.7 & | 0 & 3.29 & ||- & 490 & - & - & |- & $\begin{array}{l}25,100 \\
(1100)\end{array}$ & $\begin{array}{l}28,600 \\
(900)\end{array}$ & $\begin{array}{l}0.5 \\
(0.1)\end{array}$ \\
\hline & 9.0 & 0.09 & 3.10 & |14 & 470 & $10,200(460)$ & $\begin{array}{l}12,000 \\
630)\end{array}$ & \begin{tabular}{|l|}
1.3 \\
$(0.1)$
\end{tabular} & $\begin{array}{l}24,300 \\
580)\end{array}$ & \begin{tabular}{|l}
26,500 \\
$(650)$
\end{tabular} & $\begin{array}{l}0.6 \\
(0.1)\end{array}$ \\
\hline
\end{tabular}




\begin{tabular}{|c|c|c|c|c|c|c|c|c|c|c|c|}
\hline \multirow{2}{*}{ Clay } & \multirow{2}{*}{ pH } & \multirow{2}{*}{$\begin{array}{l}C_{\text {init }} \\
(\mathbf{L u})\end{array}$} & \multirow{2}{*}{$\begin{array}{l}C_{\text {init }} \\
\text { (La) }\end{array}$} & \multirow{2}{*}{$\begin{array}{l}C_{\text {sorb }} \\
(\mathrm{Lu})\end{array}$} & \multirow{2}{*}{$\begin{array}{l}C_{\text {sorb }} \\
(\mathrm{La}) \\
\end{array}$} & \multicolumn{3}{|l|}{$\mathbf{L u}$} & \multicolumn{3}{|l|}{ La } \\
\hline & & & & & & $K_{d}$ & $K_{\mathbf{d}, \mathbf{d e s}}$ & $\boldsymbol{R}_{\mathrm{des}}$ & $K_{d}$ & $K_{\mathrm{d}, \mathrm{des}}$ & $\boldsymbol{R}_{\mathrm{des}}$ \\
\hline & 7.3 & $\mid 1.08$ & 3.13 & $\mid 160$ & 460 & $3600(350)$ & $9400(510)$ & \begin{tabular}{|l|}
1.6 \\
$(0.1)$ \\
\end{tabular} & $\begin{array}{l}9700 \\
(980)\end{array}$ & $\begin{array}{l}11,700 \\
(440)\end{array}$ & $\begin{array}{l}1.3 \\
(0.1) \\
\end{array}$ \\
\hline & 6.7 & $\mid 3.15$ & 3.13 & 460 & 440 & $1500(50)$ & $6700(90)$ & \begin{tabular}{|l|}
2.3 \\
$(0.1)$
\end{tabular} & $\begin{array}{l}1200 \\
50)\end{array}$ & $\begin{array}{l}8800 \\
(440)\end{array}$ & \begin{tabular}{|l}
1.8 \\
$(0.1)$
\end{tabular} \\
\hline & 6.2 & $\mid 9.12$ & 3.10 & 690 & 210 & $150(60)$ & \begin{tabular}{|l}
6100 \\
$(1700)$
\end{tabular} & \begin{tabular}{|l|}
2.5 \\
$(0.7)$ \\
\end{tabular} & $120(50)$ & $\begin{array}{l}1900 \\
(870)\end{array}$ & $8(3)$ \\
\hline \multirow{10}{*}{ MX80 } & 9.8 & 0 & 0.03 & |- & 4.6 & |- & - & |- & $\begin{array}{l}6600 \\
(160)\end{array}$ & $\begin{array}{l}9600 \\
(530)\end{array}$ & $\begin{array}{l}1.6 \\
(0.1) \\
\end{array}$ \\
\hline & 10.0 & | 0.01 & 0.03 & $\mid 1.5$ & 4.3 & $5200(680)$ & $6100(890)$ & \begin{tabular}{|l|}
2.6 \\
$(0.4)$ \\
\end{tabular} & $\begin{array}{l}6800 \\
(800)\end{array}$ & $\begin{array}{l}9600 \\
(990)\end{array}$ & $\begin{array}{l}1.8 \\
(0.2)\end{array}$ \\
\hline & 9.9 & 0.03 & 0.03 & 4.5 & 4.4 & $4300(250)$ & $5300(460)$ & \begin{tabular}{|l|}
2.9 \\
$(0.2)$ \\
\end{tabular} & $\begin{array}{l}6500 \\
(760)\end{array}$ & $\begin{array}{l}7600 \\
(630)\end{array}$ & $\begin{array}{l}2.0 \\
(0.2) \\
\end{array}$ \\
\hline & 9.9 & 0.09 & 0.03 & $\mid 13$ & 4.5 & $3300(400)$ & $3900(670)$ & \begin{tabular}{|l|}
3.8 \\
$(0.6)$ \\
\end{tabular} & $\begin{array}{l}6100 \\
(90)\end{array}$ & $\begin{array}{l}7200 \\
(400)\end{array}$ & $\begin{array}{l}2.1 \\
(0.2) \\
\end{array}$ \\
\hline & 8.7 & $\mid 1.15$ & 0.03 & $\mid 160$ & 4.9 & $3000(80)$ & $3700(110)$ & \begin{tabular}{|l|}
4.0 \\
$(0.2)$ \\
\end{tabular} & $\begin{array}{l}5700 \\
(20) \\
\end{array}$ & $\begin{array}{l}6300 \\
(280)\end{array}$ & $\begin{array}{l}2.4 \\
(0.1) \\
\end{array}$ \\
\hline & 7.5 & 0 & 3.29 & |- & 480 & |- & - & |- & $\begin{array}{l}5000 \\
(200)\end{array}$ & $\begin{array}{l}7000 \\
(180)\end{array}$ & $\begin{array}{l}2.1 \\
(0.1) \\
\end{array}$ \\
\hline & 7.6 & 0.09 & 3.10 & $\mid 13$ & 450 & $2500(290)$ & $3000(340)$ & \begin{tabular}{|l|}
5.0 \\
$(0.6)$ \\
\end{tabular} & $\begin{array}{l}5300 \\
(460)\end{array}$ & $\begin{array}{l}6300 \\
(150)\end{array}$ & $\begin{array}{l}2.4 \\
(0.1) \\
\end{array}$ \\
\hline & 7.3 & $\mid 1.08$ & 3.13 & $\mid 150$ & 460 & $2300(180)$ & $2800(120)$ & \begin{tabular}{|l|}
5.3 \\
$(0.3)$ \\
\end{tabular} & $\begin{array}{l}4500 \\
(130)\end{array}$ & $\begin{array}{l}5200 \\
(120)\end{array}$ & \begin{tabular}{|l}
2.9 \\
$(0.1)$ \\
\end{tabular} \\
\hline & 6.7 & $\mid 3.15$ & 3.13 & 440 & 440 & $2200(60)$ & $2700(80)$ & \begin{tabular}{|l|}
5.2 \\
$(0.1)$ \\
\end{tabular} & $\begin{array}{l}2900 \\
(130)\end{array}$ & $\begin{array}{l}3600 \\
(280)\end{array}$ & \begin{tabular}{|l}
4.0 \\
$(0.3)$ \\
\end{tabular} \\
\hline & 6.2 & $\mid 9.12$ & 3.10 & |750 & 260 & $180(20)$ & $2400(160)$ & \begin{tabular}{|l|}
5.9 \\
$(0.4)$ \\
\end{tabular} & $180(20)$ & $\begin{array}{l}810 \\
(100)\end{array}$ & $\begin{array}{l}16 \\
(2)\end{array}$ \\
\hline \multirow{7}{*}{$\mathrm{SCa}-3$} & 8.9 & 0 & 0.03 & |- & 6.1 & - & - & ||- & $\begin{array}{l}33,000 \\
(2400)\end{array}$ & $\begin{array}{l}73,000 \\
(4100)\end{array}$ & $\begin{array}{l}0.2 \\
(0.1)\end{array}$ \\
\hline & 8.9 & | 0.01 & 0.03 & $\mid 1.5$ & 4.4 & $33,600(4200)$ & \begin{tabular}{|l|}
44,700 \\
$(670)$
\end{tabular} & \begin{tabular}{|l|}
$\begin{array}{l}0.3 \\
(0.1) \\
\end{array}$ \\
\end{tabular} & \begin{tabular}{|l}
23,800 \\
$(2400)$
\end{tabular} & $\begin{array}{l}29,600 \\
(440)\end{array}$ & $\begin{array}{l}0.5 \\
(0.1) \\
\end{array}$ \\
\hline & 9.2 & 0.03 & 0.03 & 4.9 & 4.7 & $30,200(3900)$ & | $39,900(4)$ & \begin{tabular}{|l|}
0.4 \\
$(0.1)$ \\
\end{tabular} & \begin{tabular}{|l|}
22,800 \\
$(2900)$
\end{tabular} & $\begin{array}{l}24,800 \\
(2100)\end{array}$ & $\begin{array}{l}0.6 \\
(0.1)\end{array}$ \\
\hline & 9.0 & 0.09 & 0.03 & $\mid 14$ & 4.6 & $26,700(2200)$ & \begin{tabular}{|l|}
36,000 \\
$(3200)$
\end{tabular} & \begin{tabular}{|l|}
0.4 \\
$(0.1)$ \\
\end{tabular} & \begin{tabular}{|l|l|}
$\begin{array}{l}18,100 \\
(2300)\end{array}$ \\
\end{tabular} & $\begin{array}{l}21,900 \\
(70)\end{array}$ & $\begin{array}{l}0.7 \\
0.1) \\
\end{array}$ \\
\hline & 7.6 & $\mid 1.15$ & 0.03 & $\mid 170$ & 5.1 & $25,000(2500)$ & \begin{tabular}{|l|}
32,200 \\
$(1700)$
\end{tabular} & \begin{tabular}{|l|}
0.5 \\
$(0.1)$ \\
\end{tabular} & \begin{tabular}{|l}
14,300 \\
$(2100)$
\end{tabular} & $\begin{array}{l}19,400 \\
(3500)\end{array}$ & $\begin{array}{l}0.8 \\
(0.1) \\
\end{array}$ \\
\hline & 6.5 & 0 & 3.29 & ||- & 500 & - & - & $\mid-$ & \begin{tabular}{|l|}
12,800 \\
$(1000)$
\end{tabular} & $\begin{array}{l}38,800 \\
(1900)\end{array}$ & $\begin{array}{l}0.4 \\
(0.1) \\
\end{array}$ \\
\hline & 6.9 & 0.09 & 3.10 & $\mid 14$ & 450 & $20,800(850)$ & $\begin{array}{l}25,100 \\
(2800)\end{array}$ & \begin{tabular}{|l|}
0.6 \\
$(0.1)$ \\
\end{tabular} & \begin{tabular}{|l}
14,500 \\
$(560)$
\end{tabular} & $\begin{array}{l}17,500 \\
(1100)\end{array}$ & $\begin{array}{l}0.9 \\
(0.1) \\
\end{array}$ \\
\hline
\end{tabular}




\begin{tabular}{|c|c|c|c|c|c|c|c|c|c|c|c|}
\hline \multirow{2}{*}{ Clay } & \multirow{2}{*}{ pH } & \multirow{2}{*}{$\begin{array}{l}C_{\text {init }} \\
(\mathrm{Lu})\end{array}$} & \multirow{2}{*}{$\begin{array}{l}C_{\text {init }} \\
(\mathbf{L a})\end{array}$} & \multirow{2}{*}{\begin{tabular}{|l}
$C_{\text {sorb }}$ \\
$(\mathrm{Lu})$
\end{tabular}} & \multirow{2}{*}{ 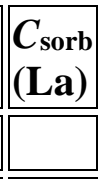 } & \multicolumn{3}{|l|}{$\mathbf{L u}$} & \multicolumn{3}{|l|}{$\mathbf{L a}$} \\
\hline & & & & & & $K_{d}$ & $K_{\mathrm{d}, \mathrm{des}}$ & $R_{\text {des }}$ & $K_{d}$ & $K_{\mathrm{d}, \mathrm{des}}$ & $R_{\mathrm{des}}$ \\
\hline & 6.8 & $\mid 1.08$ & 3.13 & $\mid 160$ & 460 & $20,000(2100)$ & $\begin{array}{l}23,000 \\
(2200)\end{array}$ & $\begin{array}{l}0.6 \\
(0.1)\end{array}$ & $\begin{array}{l}12,900 \\
(1000)\end{array}$ & \begin{tabular}{|l}
15,200 \\
$680)$
\end{tabular} & $\begin{array}{l}1.0 \\
(0.1)\end{array}$ \\
\hline & 6.5 & 3.15 & 3.13 & 470 & 470 & $10,700(920)$ & $\begin{array}{l}12,600 \\
(380)\end{array}$ & $\begin{array}{l}1.2 \\
(0.1)\end{array}$ & $\begin{array}{l}12,000 \\
(190)\end{array}$ & \begin{tabular}{|l}
13,800 \\
$(210)$
\end{tabular} & \begin{tabular}{|l}
1.1 \\
$(0.1)$
\end{tabular} \\
\hline & 5.9 & 9.12 & 3.10 & $\mid 1000$ & 350 & $430(10)$ & $6000(220)$ & \begin{tabular}{|l}
2.5 \\
$(0.1)$
\end{tabular} & $460(10)$ & $\begin{array}{l}2300 \\
(300)\end{array}$ & \begin{tabular}{|l}
6.5 \\
$(0.6)$
\end{tabular} \\
\hline
\end{tabular}


Table 5

Table 5. Sorption-desorption parameters for both lanthanides in the tested clays in the Ca medium $\left(C_{\text {init }}\right.$, meq L ${ }^{-1} ; C_{\text {sorb }}$, meq kg-1 $K_{\mathrm{d}}(\mathrm{SD}), K_{\mathrm{d}, \text { des }}(\mathrm{SD}), \mathrm{L} \mathrm{kg}^{-1}$; $\left.R_{\text {des }}(\mathrm{SD}), \%\right)$.

\begin{tabular}{|c|c|c|c|c|c|c|c|c|c|c|c|}
\hline \multirow{2}{*}{ Clay } & \multirow{2}{*}{ pH } & \multirow{2}{*}{$\begin{array}{l}C_{\text {init }} \\
(\mathrm{La})\end{array}$} & \multirow{2}{*}{\begin{tabular}{|l|}
$\begin{array}{l}C_{\text {init }} \\
(\mathbf{L u})\end{array}$ \\
\end{tabular}} & \multirow{2}{*}{$\begin{array}{l}C_{\text {sorb }} \\
\text { (La) }\end{array}$} & \multirow{2}{*}{\begin{tabular}{|l}
$C_{\text {sorb }}$ \\
$(\mathbf{L u})$
\end{tabular}} & \multicolumn{3}{|l|}{$\mathbf{L a}$} & \multicolumn{3}{|l|}{$\mathbf{L u}$} \\
\hline & & & & & & $K_{d}$ & $K_{d, d e s}$ & $\boldsymbol{R}_{\text {des }}$ & $K_{d}$ & $K_{\text {d,des }}$ & $\boldsymbol{R}_{\text {des }}$ \\
\hline \multirow{10}{*}{$\mid$ FEBEX } & |7.3 & 0 & 0.03 & - & $\mid 3.9$ & |- & - & |- & $\begin{array}{l}13,200 \\
(2700)\end{array}$ & $\begin{array}{l}13,400 \\
(1200)\end{array}$ & $\mid \begin{array}{l}1.2 \\
(0.1)\end{array}$ \\
\hline & 7.3 & 0.01 & 0.03 & 1.5 & 4.5 & $\begin{array}{l}1700 \\
(180)\end{array}$ & $2800(400)$ & \begin{tabular}{|l}
5.1 \\
$(0.7)$ \\
\end{tabular} & $\begin{array}{l}7800 \\
(770)\end{array}$ & $\begin{array}{l}9100 \\
(70)\end{array}$ & $\begin{array}{l}1.6 \\
(0.1)\end{array}$ \\
\hline & |7.3 & 0.03 & 0.03 & 4.1 & $\mid 4.2$ & $\begin{array}{l}1700 \\
(110)\end{array}$ & $2000(20)$ & $\begin{array}{l}7.3 \\
(0.1) \\
\end{array}$ & \begin{tabular}{|l}
6400 \\
$(370)$
\end{tabular} & $\begin{array}{l}8500 \\
(710) \\
\end{array}$ & $\begin{array}{l}1.8 \\
(0.1) \\
\end{array}$ \\
\hline & |7.2 & 0.09 & 0.03 & 12 & || 4.4 & $\begin{array}{l}1100 \\
(100)\end{array}$ & $1500(220)$ & $\begin{array}{l}9.7 \\
(0.9) \\
\end{array}$ & $\begin{array}{c}4900 \\
(150)\end{array}$ & $\begin{array}{l}5900 \\
(230)\end{array}$ & $\begin{array}{l}2.6 \\
(0.2) \\
\end{array}$ \\
\hline & 6.5 & 1.20 & 0.04 & 150 & $\mid 5.6$ & $700(10)$ & $990(70)$ & $14(1)$ & $\begin{array}{l}4000 \\
(180)\end{array}$ & $\begin{array}{l}4300 \\
(360) \\
\end{array}$ & $\begin{array}{l}3.5 \\
(0.3) \\
\end{array}$ \\
\hline & $\mid 6.8$ & 0 & 2.95 & - & ||400 & $\mid-$ & - & - & \begin{tabular}{|l}
1400 \\
$(200)$
\end{tabular} & $\begin{array}{l}1900 \\
(300)\end{array}$ & $\begin{array}{l}7.0 \\
(1.0) \\
\end{array}$ \\
\hline & $\mid 6.3$ & 0.10 & 3.17 & 11 & $\mid 410$ & $420(30)$ & $470(10)$ & $24(1)$ & $840(50)$ & $\begin{array}{l}1900 \\
(140)\end{array}$ & $\begin{array}{l}7.6 \\
(0.5)\end{array}$ \\
\hline & |6.4 & 1.13 & 3.07 & 120 & || 380 & $360(30)$ & $460(30)$ & $25(1)$ & $750(30)$ & $\begin{array}{l}1500 \\
(80)\end{array}$ & $\begin{array}{l}9.2 \\
(0.4)\end{array}$ \\
\hline & 6.5 & 2.93 & 3.12 & 260 & || 380 & $220(-)$ & $210(5)$ & $41(2)$ & $710(1)$ & $\begin{array}{c}980 \\
(20)\end{array}$ & ||13(1) \\
\hline & |6.2 & 9.01 & 3.01 & 620 & 250 & $130(1)$ & $200(20)$ & $43(2)$ & $190(2)$ & \begin{tabular}{|l}
550 \\
$(20)$
\end{tabular} & 22(2) \\
\hline \multirow{7}{*}{ HEC } & $\mid 7.9$ & 0 & 0.03 & - & $\mid 3.9$ & |- & - & |- & $\begin{array}{l}13,700 \\
(1200)\end{array}$ & $\begin{array}{l}14,700 \\
(440)\end{array}$ & $\begin{array}{l}0.7 \\
(0.1)\end{array}$ \\
\hline & 8.2 & 0.01 & 0.03 & 1.5 & 4.6 & $\begin{array}{l}2200 \\
(430)\end{array}$ & $3000(780)$ & \begin{tabular}{|l|}
5.2 \\
$(0.9)$ \\
\end{tabular} & \begin{tabular}{|l|}
12,000 \\
$(1100)$
\end{tabular} & \begin{tabular}{|l|l|}
14,800 \\
$(610)$
\end{tabular} & $\begin{array}{l}1.0 \\
(0.1) \\
\end{array}$ \\
\hline & 8.4 & 0.03 & 0.03 & 4.1 & $\mid 4.2$ & $\begin{array}{l}1600 \\
(190)\end{array}$ & $1900(90)$ & \begin{tabular}{|l}
7.3 \\
$(0.3)$
\end{tabular} & $\begin{array}{l}9100 \\
(550)\end{array}$ & $\begin{array}{l}11,500 \\
(390)\end{array}$ & $\begin{array}{l}1.3 \\
(0.1)\end{array}$ \\
\hline & 8.4 & 0.09 & 0.03 & 12 & 4.4 & $\begin{array}{l}1300 \\
(100)\end{array}$ & $1700(270)$ & \begin{tabular}{|l|}
8.2 \\
$(0.9)$ \\
\end{tabular} & \begin{tabular}{|l|}
8800 \\
$(40)$
\end{tabular} & \begin{tabular}{|l|}
10,200 \\
$(170)$
\end{tabular} & $\begin{array}{l}1.5 \\
(0.1) \\
\end{array}$ \\
\hline & |6.7 & 1.20 & 0.04 & 130 & $\mid 5.6$ & $350(20)$ & $1200(50)$ & $\|11(1)\|$ & $8500(-)$ & $\left(\begin{array}{l}9700 \\
(600)\end{array}\right.$ & $\begin{array}{l}1.6 \\
(0.1)\end{array}$ \\
\hline & 8.1 & 0 & 2.95 & - & ||400 & $\mid-$ & - & |- & $\begin{array}{l}1100 \\
(100)\end{array}$ & $\begin{array}{l}1300 \\
80)\end{array}$ & ||11) \\
\hline & 6.6 & 0.10 & 3.17 & 8 & 430 & $200(7)$ & $450(20)$ & $25(1)$ & $\begin{array}{l}1500 \\
(140)\end{array}$ & $\begin{array}{l}7400 \\
(200)\end{array}$ & \begin{tabular}{|l}
2.0 \\
$(0.1)$ \\
\end{tabular} \\
\hline
\end{tabular}




\begin{tabular}{|c|c|c|c|c|c|c|c|c|c|c|c|}
\hline \multirow{2}{*}{ Clay } & \multirow{2}{*}{ |pH } & \multirow{2}{*}{$\begin{array}{l}C_{\text {init }} \\
(\mathrm{La}) \\
\end{array}$} & \multirow{2}{*}{$\begin{array}{l}C_{\text {init }} \\
(\mathbf{L u})\end{array}$} & \multirow{2}{*}{\begin{tabular}{|l}
$\begin{array}{l}C_{\text {sorb }} \\
(\text { La) }\end{array}$ \\
\end{tabular}} & \multirow{2}{*}{$\begin{array}{l}C_{\text {sorb }} \\
(\mathbf{L u})\end{array}$} & \multicolumn{3}{|l|}{ La } & \multicolumn{3}{|l|}{$\mathbf{L u}$} \\
\hline & & & & & & $K_{d}$ & $K_{\mathbf{d}, \mathbf{d e s}}$ & $\boldsymbol{R}_{\mathrm{des}}$ & $K_{d}$ & $K_{\mathbf{d}, \mathbf{d e s}}$ & $R_{\text {des }}$ \\
\hline & 6.5 & 1.13 & 3.07 & 90 & 410 & $180(30)$ & $420(100)$ & | $27(5)$ & $\begin{array}{l}1300 \\
(60)\end{array}$ & \begin{tabular}{|l}
4700 \\
$(80)$
\end{tabular} & $\begin{array}{l}3.1 \\
(0.1) \\
\end{array}$ \\
\hline & $\mid 6.7$ & 2.93 & 3.12 & | 220 & 420 & $150(3)$ & $420(3)$ & $26(1)$ & $\begin{array}{l}1200 \\
(20)\end{array}$ & \begin{tabular}{|l}
4200 \\
$(40)$
\end{tabular} & $\begin{array}{l}3.6 \\
(0.1)\end{array}$ \\
\hline & 6.5 & 9.01 & 3.01 & $\mid 370$ & ||290 & $60(1)$ & $160(20)$ & $46(2)$ & $270(1)$ & \begin{tabular}{|l}
760 \\
$(20)$ \\
\end{tabular} & $17(1)$ \\
\hline \multirow{10}{*}{ MX80 } & 8.0 & 0 & 0.03 & ||$-$ & $\mid 3.8$ & $\mid-$ & |- & |- & $\begin{array}{l}9100 \\
(940)\end{array}$ & \begin{tabular}{|l|}
12,300 \\
$(1000)$
\end{tabular} & $\begin{array}{l}1.2 \\
(0.1)\end{array}$ \\
\hline & $\mid 7.9$ & 0.01 & 0.03 & $\mid 1.6$ & $\mid 4.7$ & $\begin{array}{l}14,000 \\
(1800)\end{array}$ & $19,100(300)$ & $\begin{array}{l}0.8 \\
(0.1)\end{array}$ & $\begin{array}{l}15,700 \\
600)\end{array}$ & \begin{tabular}{|l|}
$\begin{array}{l}16,700 \\
(490)\end{array}$ \\
\end{tabular} & $\begin{array}{l}0.9 \\
(0.1)\end{array}$ \\
\hline & | 8.1 & 0.03 & 0.03 & 4.5 & 4.3 & $\begin{array}{l}10,600 \\
(490)\end{array}$ & $\begin{array}{l}12,300 \\
(1200)\end{array}$ & \begin{tabular}{|l}
1.2 \\
$(0.1)$
\end{tabular} & $\begin{array}{l}12,800 \\
590)\end{array}$ & \begin{tabular}{|l|}
16,300 \\
$(910)$
\end{tabular} & $\begin{array}{l}0.9 \\
(0.1)\end{array}$ \\
\hline & 8.1 & 0.09 & 0.03 & |13 & 4.4 & $\begin{array}{l}10,800 \\
(520)\end{array}$ & $\begin{array}{l}14,400 \\
(1200)\end{array}$ & \begin{tabular}{|l}
1.0 \\
$(0.1)$
\end{tabular} & $\begin{array}{l}12,000 \\
(800)\end{array}$ & \begin{tabular}{|l|}
13,400 \\
$(50)$
\end{tabular} & $\begin{array}{l}1.1 \\
(0.1) \\
\end{array}$ \\
\hline & $\mid 6.7$ & 1.20 & 0.04 & ||130 & $\mid 5.8$ & $390(30)$ & $1200(30)$ & $\mid 11(-)$ & \begin{tabular}{|l}
11,400 \\
$(1300)$
\end{tabular} & \begin{tabular}{|l|}
13,000 \\
$(1200)$ \\
\end{tabular} & $\begin{array}{l}1.2 \\
(0.1)\end{array}$ \\
\hline & $\mid 6.6$ & 0 & 2.95 & $\mid-$ & ||340 & $\mid-$ & |- & $\mid$ & $460(4)$ & $\begin{array}{l}700 \\
(20) \\
\end{array}$ & $18(-)$ \\
\hline & 6.5 & 0.10 & 3.17 & $\mid 11$ & |390 & $500(30)$ & $490(40)$ & | 24 (2) & $740(20)$ & $\begin{array}{l}3300 \\
(130)\end{array}$ & $\begin{array}{l}4.5 \\
(0.1) \\
\end{array}$ \\
\hline & | 6.4 & 1.13 & 3.07 & $\mid 100$ & $\mid 380$ & $230(40)$ & $320(60)$ & $32(4)$ & $650(40)$ & $\begin{array}{l}2700 \\
(130) \\
\end{array}$ & $\begin{array}{l}5.4 \\
(0.2) \\
\end{array}$ \\
\hline & 6.5 & 2.93 & 3.12 & $\mid 250$ & $\mid 380$ & $200(5)$ & $\mid 320(6)$ & $\mid 32(2)$ & $620(20)$ & $\begin{array}{l}1200 \\
(20)\end{array}$ & | $11(1)$ \\
\hline & 6.3 & 9.01 & 3.01 & | 440 & || 220 & $70(1)$ & $\mid 140(1)$ & $\mid 51(3)$ & $140(1)$ & \begin{tabular}{|l|}
470 \\
$(2)$ \\
\end{tabular} & $24(2)$ \\
\hline \multirow{7}{*}{ SCa-3 } & $\mid 7.1$ & 0 & 0.03 & |- & $\mid 3.8$ & $\mid-$ & I- & $\mid-$ & \begin{tabular}{|l}
11,200 \\
$(990)$
\end{tabular} & \begin{tabular}{|l|}
12,200 \\
$(2200)$
\end{tabular} & $\begin{array}{l}1.2 \\
(0.2)\end{array}$ \\
\hline & || 7.7 & 0.01 & 0.03 & $\mid 1.6$ & 4.6 & $\begin{array}{l}5100 \\
(270)\end{array}$ & $5900(360)$ & $\begin{array}{l}2.6 \\
(0.1)\end{array}$ & \begin{tabular}{|l}
18,100 \\
$(1800)$
\end{tabular} & \begin{tabular}{|l|}
25,200 \\
$(3300)$ \\
\end{tabular} & $\begin{array}{l}0.6 \\
(0.1) \\
\end{array}$ \\
\hline & $\mid 7.6$ & 0.03 & 0.03 & $\mid 4.4$ & 4.3 & $\begin{array}{l}4800 \\
(540)\end{array}$ & $5200(20)$ & \begin{tabular}{|l}
2.9 \\
$(0.1)$
\end{tabular} & $\begin{array}{l}13,600 \\
(1700)\end{array}$ & $\begin{array}{l}18,100 \\
(2200)\end{array}$ & $\begin{array}{l}0.8 \\
(0.1)\end{array}$ \\
\hline & | 7.3 & 0.09 & 0.03 & $\mid 13$ & 4.4 & $\begin{array}{l}3100 \\
(420)\end{array}$ & $4000(750)$ & \begin{tabular}{|l}
3.8 \\
$(0.7)$
\end{tabular} & \begin{tabular}{|l}
11,300 \\
$(890)$
\end{tabular} & \begin{tabular}{|l|}
$\begin{array}{l}13,000 \\
(1200)\end{array}$ \\
\end{tabular} & $\begin{array}{l}1.2 \\
(0.1)\end{array}$ \\
\hline & |6.6 & 1.20 & 0.04 & 160 & || 5.7 & $870(10)$ & $1400(50)$ & $10(1)$ & $\begin{array}{l}10,600 \\
(1300)\end{array}$ & \begin{tabular}{|l|}
12,600 \\
$(910)$
\end{tabular} & $\begin{array}{l}1.2 \\
(0.1) \\
\end{array}$ \\
\hline & 6.5 & 0 & 2.95 & ||- & $\mid 380$ & $\mid-$ & |- & - & $850(90)$ & $\begin{array}{l}1800 \\
(35)\end{array}$ & $12(1)$ \\
\hline & | 6.4 & 0.10 & 3.17 & $\mid 12$ & $\mid 440$ & $610(30)$ & $570(30)$ & | 21 (1) & $\begin{array}{l}1600 \\
50)\end{array}$ & $\begin{array}{l}4300 \\
(530)\end{array}$ & $\begin{array}{l}3.5 \\
(0.4) \\
\end{array}$ \\
\hline
\end{tabular}




\begin{tabular}{|c|c|c|c|c|c|c|c|c|c|c|c|}
\hline \multirow{2}{*}{ Clay } & \multirow{2}{*}{ pH } & \multirow{2}{*}{$\begin{array}{l}C_{\text {init }} \\
\text { (La) }\end{array}$} & \multirow{2}{*}{\begin{tabular}{|l|}
$C_{\text {init }}$ \\
$(\mathbf{L u})$
\end{tabular}} & \multirow{2}{*}{\begin{tabular}{|l}
$C_{\text {sorb }}$ \\
$(\mathrm{La})$
\end{tabular}} & \multirow{2}{*}{\begin{tabular}{|l|}
$C_{\text {sorb }}$ \\
$(\mathbf{L u})$
\end{tabular}} & \multicolumn{3}{|l|}{ La } & \multicolumn{3}{|l|}{$\mathbf{L u}$} \\
\hline & & & & & & $K_{\mathrm{d}}$ & $K_{\mathrm{d}, \mathrm{des}}$ & $\boldsymbol{R}_{\mathrm{des}}$ & $K_{d}$ & $K_{\mathrm{d}, \mathrm{des}}$ & $R_{\text {des }}$ \\
\hline & 6.3 & 1.13 & 3.07 & 130 & 420 & $450(60)$ & $510(40)$ & $23(1)$ & $\begin{array}{l}1400 \\
(60)\end{array}$ & $\begin{array}{l}3100 \\
(130)\end{array}$ & $\begin{array}{l}4.8 \\
(0.3)\end{array}$ \\
\hline & 6.6 & 2.93 & 3.12 & 320 & 420 & $390(20)$ & $470(9)$ & $25(2)$ & $\begin{array}{l}1200 \\
50)\end{array}$ & $\left(\begin{array}{l}1900 \\
(190)\end{array}\right.$ & $\begin{array}{l}7.6 \\
(0.5)\end{array}$ \\
\hline & 6.0 & 9.01 & 3.01 & 700 & $\mid 300$ & $160(1)$ & $330(6)$ & | 31 (2) & $290(5)$ & $\left(\begin{array}{c}860 \\
50)\end{array}\right.$ & || $15(1)$ \\
\hline
\end{tabular}


Table 6. Sorption-desorption parameters for both lanthanides in the tested clays in the Ca medium $\left(C_{\text {init }}\right.$, meq L ${ }^{-1} ; C_{\text {sorb }}$, meq kg ${ }^{-1} ; K_{\mathrm{d}}(\mathrm{SD}), K_{\mathrm{d}, \mathrm{des}}(\mathrm{SD}), \mathrm{L} \mathrm{kg}^{-1}$; $\left.R_{\text {des }}(\mathrm{SD}), \%\right)$.

\begin{tabular}{|c|c|c|c|c|c|c|c|c|c|c|c|}
\hline \multirow{2}{*}{ Clay } & \multirow{2}{*}{ pH } & \multirow{2}{*}{\begin{tabular}{|l}
$C_{\text {init }}$ \\
$(\mathbf{L u})$
\end{tabular}} & \multirow{2}{*}{$\begin{array}{l}C_{\text {init }} \\
\text { (La) } \\
\end{array}$} & \multirow{2}{*}{$\begin{array}{l}C_{\text {sorb }} \\
(\mathbf{L u})\end{array}$} & \multirow{2}{*}{\begin{tabular}{|l}
$C_{\text {sorb }}$ \\
(La)
\end{tabular}} & \multicolumn{3}{|l|}{$\mathbf{L u}$} & \multicolumn{3}{|l|}{$\mathbf{L a}$} \\
\hline & & & & & & $K_{d}$ & $K_{\mathrm{d}, \mathrm{des}}$ & $R_{\text {des }}$ & $K_{\mathrm{d}}$ & $K_{\mathrm{d}, \mathrm{des}}$ & $R_{\text {des }}$ \\
\hline \multirow{10}{*}{ FEBEX } & | 7.3 & 0 & 0.04 & - & 5.6 & - & $\|-$ & |- & $\begin{array}{l}3600 \\
(760)\end{array}$ & $\begin{array}{l}2900 \\
(180)\end{array}$ & \begin{tabular}{|l}
5.1 \\
$(0.3)$ \\
\end{tabular} \\
\hline & | 7.4 & 0.01 & 0.03 & 1.4 & 4.3 & \begin{tabular}{|l|}
10,700 \\
$(2000)$ \\
\end{tabular} & $\begin{array}{l}11,400 \\
(1200)\end{array}$ & \begin{tabular}{|l|}
$\begin{array}{l}1.3 \\
(0.1)\end{array}$ \\
\end{tabular} & $\begin{array}{l}2500 \\
(230)\end{array}$ & $\begin{array}{l}2600 \\
(310)\end{array}$ & \begin{tabular}{|l}
5.6 \\
$(0.6)$ \\
\end{tabular} \\
\hline & | 7.3 & 0.03 & 0.03 & 4.2 & 4.1 & \begin{tabular}{|l|}
6400 \\
$(370)$
\end{tabular} & \begin{tabular}{|l}
8500 \\
$(710)$
\end{tabular} & \begin{tabular}{|l|}
$\begin{array}{l}1.8 \\
(0.1)\end{array}$ \\
\end{tabular} & $\begin{array}{l}1700 \\
(110)\end{array}$ & $\begin{array}{l}2000 \\
(20)\end{array}$ & \begin{tabular}{|l}
7.3 \\
$(0.1)$ \\
\end{tabular} \\
\hline & | 7.3 & 0.09 & 0.03 & 13 & 4.0 & \begin{tabular}{|l}
4800 \\
$(580)$ \\
\end{tabular} & \begin{tabular}{|l}
6800 \\
$(840)$
\end{tabular} & \begin{tabular}{|l|}
2.2 \\
$(0.3)$ \\
\end{tabular} & $\begin{array}{l}1200 \\
(120)\end{array}$ & $\begin{array}{l}1400 \\
(80)\end{array}$ & $\begin{array}{l}10 \\
(1)\end{array}$ \\
\hline & |6.4 & 1.27 & 0.04 & 160 & 4.4 & \begin{tabular}{|l}
880 \\
$(20)$
\end{tabular} & $\begin{array}{l}1100 \\
(4)\end{array}$ & $\begin{array}{l}12 \\
(1)\end{array}$ & $600(6)$ & $\begin{array}{l}700 \\
(40)\end{array}$ & $\mid \begin{array}{c}18 \\
(1)\end{array}$ \\
\hline & |6.6 & 0 & 2.62 & - & 330 & - & $\|-$ & |- & $\begin{array}{l}630 \\
60)\end{array}$ & $\begin{array}{l}670 \\
(110)\end{array}$ & $\mid \begin{array}{l}19 \\
(2)\end{array}$ \\
\hline & |6.4 & 0.10 & 3.05 & 15 & 320 & \begin{tabular}{|l}
3000 \\
$(420)$
\end{tabular} & $\begin{array}{l}4200 \\
(380)\end{array}$ & \begin{tabular}{|l|}
$\begin{array}{l}3.6 \\
(0.3)\end{array}$ \\
\end{tabular} & $\begin{array}{l}360 \\
(20)\end{array}$ & $\begin{array}{l}450 \\
(40)\end{array}$ & $\begin{array}{l}25 \\
(1) \\
\end{array}$ \\
\hline & | 6.4 & 1.24 & 2.97 & 160 & 300 & \begin{tabular}{|l}
770 \\
$(40)$ \\
\end{tabular} & $\begin{array}{l}1100 \\
(70)\end{array}$ & $\begin{array}{l}12 \\
(1)\end{array}$ & $\begin{array}{l}300 \\
(20)\end{array}$ & $\begin{array}{l}320 \\
(20)\end{array}$ & $\begin{array}{l}33 \\
(1) \\
\end{array}$ \\
\hline & 6.5 & 3.12 & 2.93 & 380 & 260 & $710(1)$ & $\begin{array}{l}980 \\
(20)\end{array}$ & $\begin{array}{l}13 \\
(1) \\
\end{array}$ & $220(-)$ & $210(5)$ & $\begin{array}{l}41 \\
(0)\end{array}$ \\
\hline & 6.5 & 9.19 & 2.94 & 1100 & 260 & $500(5)$ & $\begin{array}{l}610 \\
(20)\end{array}$ & $\begin{array}{l}20 \\
(2)\end{array}$ & $220(-)$ & $200(8)$ & $\begin{array}{l}43 \\
(1) \\
\end{array}$ \\
\hline \multirow{7}{*}{ HEC } & $\mid 7.7$ & 0 & 0.04 & - & 5.5 & - & $\|-$ & |- & $\begin{array}{l}2100 \\
(260)\end{array}$ & $\begin{array}{l}3000 \\
(160)\end{array}$ & \begin{tabular}{|l}
5.0 \\
$(0.3)$
\end{tabular} \\
\hline & 8.5 & 0.01 & 0.03 & 1.4 & 4.2 & \begin{tabular}{|l|}
9300 \\
$(50)$ \\
\end{tabular} & $\begin{array}{l}12,100 \\
60)\end{array}$ & \begin{tabular}{|l|}
$\begin{array}{l}1.2 \\
(0.1)\end{array}$ \\
\end{tabular} & $\begin{array}{l}2100 \\
(150)\end{array}$ & $\begin{array}{l}2200 \\
(120)\end{array}$ & \begin{tabular}{|l}
6.4 \\
$(0.4)$ \\
\end{tabular} \\
\hline & || 8.4 & 0.03 & 0.03 & 4.2 & 4.1 & $\begin{array}{l}9100 \\
(550)\end{array}$ & $\begin{array}{l}11,500 \\
(390)\end{array}$ & \begin{tabular}{|l|}
$\begin{array}{l}1.3 \\
(0.1)\end{array}$ \\
\end{tabular} & $\begin{array}{l}1600 \\
(190)\end{array}$ & $\begin{array}{l}1900 \\
(90)\end{array}$ & $\begin{array}{l}7.3 \\
(0.3) \\
\end{array}$ \\
\hline & 8.4 & 0.09 & 0.03 & 13 & |3.9 & \begin{tabular}{|l}
8800 \\
$(660)$ \\
\end{tabular} & $\begin{array}{l}9300 \\
(300)\end{array}$ & \begin{tabular}{|l|}
$\begin{array}{l}1.6 \\
(0.1)\end{array}$ \\
\end{tabular} & $\begin{array}{l}1100 \\
(30)\end{array}$ & $\begin{array}{l}1300 \\
(170)\end{array}$ & $\begin{array}{l}11 \\
(1)\end{array}$ \\
\hline & $\mid 7.1$ & 1.27 & 0.04 & 170 & 4.5 & \begin{tabular}{|l|}
1700 \\
$(8)$
\end{tabular} & $\left(\begin{array}{l}5000 \\
(270)\end{array}\right.$ & $\begin{array}{l}3.0 \\
(0.1)\end{array}$ & $\left(\begin{array}{l}640 \\
(50)\end{array}\right.$ & $\begin{array}{l}670 \\
(100)\end{array}$ & $\begin{array}{l}19 \\
(2)\end{array}$ \\
\hline & | 7.4 & 0 & 2.62 & - & 320 & - & - & |- & $\begin{array}{l}660 \\
(300)\end{array}$ & $\begin{array}{l}640 \\
(20)\end{array}$ & $\mid \begin{array}{c}19 \\
(1)\end{array}$ \\
\hline & $\mid 6.0$ & 0.10 & 3.05 & 15 & 270 & $\begin{array}{l}9100 \\
(380)\end{array}$ & $\begin{array}{l}10,200 \\
(490)\end{array}$ & \begin{tabular}{|l}
1.5 \\
$(0.1)$
\end{tabular} & $220(1)$ & $\begin{array}{l}1400 \\
(230)\end{array}$ & $\begin{array}{l}10 \\
(1)\end{array}$ \\
\hline
\end{tabular}




\begin{tabular}{|c|c|c|c|c|c|c|c|c|c|c|c|}
\hline \multirow{2}{*}{ Clay } & \multirow{2}{*}{ pH } & \multirow{2}{*}{$\begin{array}{l}C_{\text {init }} \\
(\mathrm{Lu}) \\
\end{array}$} & \multirow{2}{*}{$\begin{array}{l}C_{\text {init }} \\
\text { (La) }\end{array}$} & \multirow{2}{*}{$\begin{array}{l}C_{\text {sorb }} \\
(\mathrm{Lu}) \\
\end{array}$} & \multirow{2}{*}{\begin{tabular}{|l}
$C_{\text {sorb }}$ \\
(La)
\end{tabular}} & \multicolumn{3}{|l|}{$\mathbf{L u}$} & \multicolumn{3}{|l|}{ La } \\
\hline & & & & & & $K_{d}$ & $K_{d, d e s}$ & $\boldsymbol{R}_{\text {des }}$ & $K_{d}$ & $K_{\mathbf{d}, \mathrm{des}}$ & $\boldsymbol{R}_{\text {des }}$ \\
\hline & 6.7 & 1.24 & 2.97 & 170 & | 250 & $\begin{array}{l}1600 \\
(30)\end{array}$ & \begin{tabular}{|l}
4400 \\
$(190)$ \\
\end{tabular} & \begin{tabular}{|l|}
3.4 \\
$(0.2)$ \\
\end{tabular} & $180(6)$ & \begin{tabular}{|l|}
650 \\
$(20)$
\end{tabular} & \begin{tabular}{|l}
19 \\
$(1)$
\end{tabular} \\
\hline & 6.7 & 3.12 & 2.93 & 420 & || 220 & $\begin{array}{l}1200 \\
(20)\end{array}$ & \begin{tabular}{|l}
4200 \\
$(40)$
\end{tabular} & $\begin{array}{l}3.6 \\
(0.1)\end{array}$ & $150(3)$ & $420(3)$ & $\begin{array}{l}26 \\
(2)\end{array}$ \\
\hline & 6.5 & 9.19 & 2.94 & 1100 & ||200 & $470(5)$ & \begin{tabular}{|l|}
1800 \\
$(20)$
\end{tabular} & \begin{tabular}{|l|}
7.7 \\
$(0.1)$ \\
\end{tabular} & $120(1)$ & $330(4)$ & \begin{tabular}{|l}
31 \\
$(2)$
\end{tabular} \\
\hline \multirow{10}{*}{ MX80 } & $\mid 7.8$ & 0 & 0.04 & - & $\mid 5.7$ & I- & - & I- & \begin{tabular}{|l|}
13,500 \\
$(1200)$
\end{tabular} & $\begin{array}{l}24,000 \\
(310)\end{array}$ & $\begin{array}{l}0.6 \\
(0.1)\end{array}$ \\
\hline & 8.1 & 0.01 & 0.03 & 1.4 & $\mid 4.5$ & $\left(\begin{array}{l}15,400 \\
(1900)\end{array}\right)$ & \begin{tabular}{|l}
28,700 \\
$(10)$
\end{tabular} & $\begin{array}{l}0.5 \\
(0.1)\end{array}$ & $\begin{array}{l}11,200 \\
520)\end{array}$ & $\left(\begin{array}{l}14,100 \\
(1400)\end{array}\right)$ & $\mid \begin{array}{l}1.1 \\
(0.1)\end{array}$ \\
\hline & 8.1 & 0.03 & 0.03 & 4.3 & $\mid 4.5$ & {$\left[\begin{array}{l}12,800 \\
(590)\end{array}\right)$} & \begin{tabular}{|l}
16,300 \\
$(910)$
\end{tabular} & $\begin{array}{l}0.9 \\
(0.1)\end{array}$ & \begin{tabular}{|l}
10,600 \\
$(490)$
\end{tabular} & $\left(\begin{array}{l}12,300 \\
(1200)\end{array}\right)$ & $\mid \begin{array}{l}1.2 \\
(0.1)\end{array}$ \\
\hline & 8.0 & 0.09 & 0.03 & 13 & $\mid 4.4$ & $\left.\begin{array}{c}12,000 \\
(1500)\end{array}\right)$ & $\begin{array}{l}15,400 \\
(1900)\end{array}$ & $\begin{array}{l}1.0 \\
(0.1)\end{array}$ & $\begin{array}{l}9700 \\
(890)\end{array}$ & $\begin{array}{l}10,900 \\
(280)\end{array}$ & \begin{tabular}{|l}
1.4 \\
$(0.1)$
\end{tabular} \\
\hline & |6.7 & 1.27 & 0.04 & 170 & $\mid 4.4$ & $\begin{array}{l}1100 \\
(90)\end{array}$ & \begin{tabular}{|l|}
2700 \\
$(480)$
\end{tabular} & \begin{tabular}{|l|}
5.5 \\
$(0.9)$ \\
\end{tabular} & \begin{tabular}{|l}
550 \\
$(30)$ \\
\end{tabular} & $\begin{array}{l}710 \\
(100)\end{array}$ & \begin{tabular}{|l}
18 \\
$(2)$
\end{tabular} \\
\hline & $\mid 6.3$ & 0 & 2.62 & - & || 310 & I- & - & I- & \begin{tabular}{|l}
600 \\
$(20)$
\end{tabular} & $\begin{array}{l}1400 \\
(70)\end{array}$ & \begin{tabular}{|l}
10 \\
$(1)$
\end{tabular} \\
\hline & $\mid 6.5$ & 0.10 & 3.05 & 16 & ||330 & $\begin{array}{l}9500 \\
(200)\end{array}$ & $\begin{array}{l}11,300 \\
(940)\end{array}$ & \begin{tabular}{|l|}
1.4 \\
$(0.1)$ \\
\end{tabular} & $360(4)$ & $680(-)$ & $\begin{array}{l}19 \\
(-)\end{array}$ \\
\hline & $\mid 6.6$ & 1.24 & 2.97 & 150 & ||280 & \begin{tabular}{|l}
680 \\
$(20)$ \\
\end{tabular} & \begin{tabular}{|l}
1600 \\
$(80)$
\end{tabular} & \begin{tabular}{|l|}
8.6 \\
$(0.4)$ \\
\end{tabular} & \begin{tabular}{|l}
260 \\
$(20)$
\end{tabular} & $\begin{array}{l}440 \\
(40)\end{array}$ & \begin{tabular}{|l}
26 \\
$(2)$
\end{tabular} \\
\hline & 6.5 & 3.12 & 2.93 & 380 & | 250 & \begin{tabular}{|l}
620 \\
$(20)$ \\
\end{tabular} & \begin{tabular}{|l|}
1200 \\
$(20)$
\end{tabular} & $\begin{array}{l}11 \\
(1)\end{array}$ & $200(5)$ & $320(6)$ & \begin{tabular}{|l}
32 \\
$(3)$
\end{tabular} \\
\hline & $\mid 6.3$ & 9.19 & 2.94 & 1000 & | 220 & $410(1)$ & $750(3)$ & $\begin{array}{l}17 \\
(1)\end{array}$ & $150(-)$ & $220(3)$ & $\begin{array}{l}40 \\
(1)\end{array}$ \\
\hline \multirow{7}{*}{$\mathrm{SCa}-3$} & | 7.0 & 0 & 0.04 & - & $\mid 5.9$ & I- & - & I- & \begin{tabular}{|l|}
16,600 \\
$(1700)$ \\
\end{tabular} & $\begin{array}{l}28,000 \\
(550)\end{array}$ & \begin{tabular}{|l|}
0.6 \\
$(0.1)$ \\
\end{tabular} \\
\hline & |7.6 & 0.01 & 0.03 & 1.5 & $\mid 4.4$ & \begin{tabular}{|l}
15,500 \\
$(1900)$ \\
\end{tabular} & \begin{tabular}{|l|}
29,100 \\
$(440)$
\end{tabular} & \begin{tabular}{|l|}
0.5 \\
$(0.1)$ \\
\end{tabular} & $\begin{array}{l}5200 \\
(250)\end{array}$ & $\begin{array}{l}6200 \\
(500)\end{array}$ & \begin{tabular}{|l|}
2.4 \\
$(0.2)$ \\
\end{tabular} \\
\hline & |7.6 & 0.03 & 0.03 & 4.3 & $\mid 4.4$ & \begin{tabular}{|l}
13,600 \\
$(1700)$
\end{tabular} & \begin{tabular}{|l}
18,100 \\
$(2200)$ \\
\end{tabular} & \begin{tabular}{|l|}
0.8 \\
$(0.1)$ \\
\end{tabular} & $\begin{array}{l}4800 \\
(540)\end{array}$ & $\begin{array}{l}5200 \\
(20)\end{array}$ & \begin{tabular}{|l|}
2.9 \\
$(0.1)$ \\
\end{tabular} \\
\hline & $\mid 7.6$ & 0.09 & 0.03 & 13 & $\mid 4.4$ & \begin{tabular}{|l}
11,400 \\
$(970)$
\end{tabular} & \begin{tabular}{|l}
12,500 \\
$(350)$
\end{tabular} & \begin{tabular}{|l|}
1.2 \\
$(0.1)$ \\
\end{tabular} & $\begin{array}{l}3900 \\
(490)\end{array}$ & $\begin{array}{l}4500 \\
(460)\end{array}$ & \begin{tabular}{|l|}
3.3 \\
$(0.2)$ \\
\end{tabular} \\
\hline & $\mid 6.5$ & 1.27 & 0.04 & 180 & $\mid 4.8$ & $\begin{array}{l}1600 \\
(30)\end{array}$ & \begin{tabular}{|l|}
2200 \\
$(80)$
\end{tabular} & \begin{tabular}{|l|}
6.5 \\
$(0.2)$ \\
\end{tabular} & $\begin{array}{c}860 \\
(50)\end{array}$ & $\begin{array}{l}890 \\
(100)\end{array}$ & $\begin{array}{l}15 \\
(2)\end{array}$ \\
\hline & $\mid 6.2$ & 0 & 2.62 & - & || 290 & - & - & I- & \begin{tabular}{|l}
430 \\
$(70)$ \\
\end{tabular} & $\begin{array}{l}530 \\
(120) \\
\end{array}$ & $\begin{array}{l}23 \\
(4)\end{array}$ \\
\hline & $\mid 6.5$ & 0.10 & 3.05 & 15 & $\mid 350$ & $\begin{array}{l}4600 \\
(290)\end{array}$ & \begin{tabular}{|l}
6600 \\
$(930)$
\end{tabular} & \begin{tabular}{|l|}
2.3 \\
$(0.4)$ \\
\end{tabular} & $\begin{array}{l}510 \\
(10)\end{array}$ & \begin{tabular}{|l}
650 \\
$(30)$ \\
\end{tabular} & $\begin{array}{l}19 \\
(1) \\
\end{array}$ \\
\hline
\end{tabular}




\begin{tabular}{|c|c|c|c|c|c|c|c|c|c|c|c|}
\hline \multirow{2}{*}{ Clay } & \multirow{2}{*}{ pH } & \multirow{2}{*}{$\begin{array}{l}C_{\text {init }} \\
(\mathbf{L u})\end{array}$} & \multirow{2}{*}{$\begin{array}{l}C_{\text {init }} \\
\text { (La) }\end{array}$} & \multirow{2}{*}{$\begin{array}{l}C_{\text {sorb }} \\
(\mathrm{Lu})\end{array}$} & \multirow{2}{*}{$\begin{array}{l}C_{\text {sorb }} \\
\text { (La) }\end{array}$} & \multicolumn{3}{|l|}{$\mathbf{L u}$} & \multicolumn{3}{|l|}{ La } \\
\hline & & & & & & $K_{d}$ & $K_{\mathrm{d}, \mathrm{des}}$ & $\boldsymbol{R}_{\text {des }}$ & $K_{d}$ & $K_{\mathrm{d}, \mathrm{des}}$ & $R_{\text {des }}$ \\
\hline & $\mid 6.6$ & 1.24 & 2.97 & 170 & 340 & \begin{tabular}{|l}
1400 \\
$(100)$ \\
\end{tabular} & $\begin{array}{l}2000 \\
(70)\end{array}$ & \begin{tabular}{|l|}
7.3 \\
$(0.3)$ \\
\end{tabular} & $\begin{array}{l}450 \\
(20) \\
\end{array}$ & \begin{tabular}{|l}
560 \\
$(40)$ \\
\end{tabular} & $\begin{array}{l}22 \\
(1)\end{array}$ \\
\hline & $\mid 6.6$ & 3.12 & 2.93 & 420 & 320 & \begin{tabular}{|l}
1200 \\
$(50)$
\end{tabular} & $\begin{array}{l}1900 \\
(190)\end{array}$ & \begin{tabular}{|l|}
7.6 \\
$(0.5)$ \\
\end{tabular} & $\begin{array}{l}390 \\
(20)\end{array}$ & $470(9)$ & $\begin{array}{l}25 \\
(1)\end{array}$ \\
\hline & $\mid 6.3$ & 9.19 & 2.94 & 1100 & 290 & $\begin{array}{l}660 \\
(20)\end{array}$ & $\begin{array}{l}1300 \\
(1)\end{array}$ & $\begin{array}{l}10 \\
(1)\end{array}$ & \begin{tabular}{|l}
290 \\
$(10)$
\end{tabular} & $340(2)$ & $\begin{array}{l}31 \\
(1)\end{array}$ \\
\hline
\end{tabular}


Table 7. Changes in the $K_{\mathrm{d}}$ of the Ln (1) due to changes in the concentration of the $\operatorname{Ln}(2)$ : ratio values of $K_{\mathrm{d}}$ of $\operatorname{Ln}(1)$ at varying concentrations of the $\operatorname{Ln}(2)$.

\begin{tabular}{|c|c|c|c|c|c|}
\hline \multirow[t]{2}{*}{$C_{\text {init }}(\operatorname{Ln}(1))$ meq $\mathrm{L}^{-1}$} & \multirow[t]{2}{*}{$C_{\text {init }}(\operatorname{Ln}(2))$ meq $\mathrm{L}^{-1}$} & \multicolumn{4}{|c|}{ Ratio values of $K_{d}(\operatorname{Ln}(1))$} \\
\hline & & \multicolumn{2}{|c|}{ FEBEX HEC } & \multicolumn{2}{|c|}{\begin{tabular}{|l|l|} 
MX80 & SCa-3 \\
\end{tabular}} \\
\hline \multicolumn{6}{|l|}{ Water medium } \\
\hline \multicolumn{6}{|l|}{ 1:La; $2: \mathrm{Lu}$} \\
\hline \multirow[t]{2}{*}{0.09} & 0.03 & 1.6 & 1.9 & 1.5 & 1.2 \\
\hline & 3 & & & & \\
\hline \multirow[t]{2}{*}{1} & 0.03 & 1.6 & 1.6 & 1.0 & 1.3 \\
\hline & 3 & & & & \\
\hline \multirow[t]{2}{*}{0.03} & 0 & 0.9 & 1.8 & 1.0 & 1.4 \\
\hline & 0.03 & & & & \\
\hline \multirow[t]{2}{*}{3} & 0 & 1.3 & 21 & 1.9 & 1.1 \\
\hline & 3 & & & & \\
\hline \multicolumn{6}{|l|}{ 1:Lu; 2:La } \\
\hline \multirow[t]{2}{*}{0.09} & 0.03 & 1.9 & 1.2 & 1.3 & 1.3 \\
\hline & 3 & & & D. & . \\
\hline \multirow[t]{2}{*}{1} & 0.03 & 1.1 & 1.4 & 1.3 & 1.3 \\
\hline & 3 & & & & \\
\hline \multirow[t]{2}{*}{0.03} & 0 & 1.0 & 1.2 & 1.0 & 1.6 \\
\hline & 0.03 & & & & \\
\hline \multirow[t]{2}{*}{3} & 0 & 1.2 & 6.7 & 1.4 & 2.5 \\
\hline & 3 & & & & \\
\hline \multicolumn{6}{|l|}{ Ca medium } \\
\hline \multicolumn{6}{|l|}{ 1:La; $2: \mathrm{Lu}$} \\
\hline \multirow[t]{2}{*}{0.09} & 0.03 & 2.6 & 6.5 & 22 & 5.1 \\
\hline & 3 & & & & \\
\hline \multirow[t]{2}{*}{1} & 0.03 & 1.9 & 1.9 & 1.7 & 1.9 \\
\hline & 3 & & & & \\
\hline \multirow[t]{2}{*}{0.03} & 0 & 2.1 & 1.3 & 1.3 & 3.4 \\
\hline & 0.03 & & & & \\
\hline \multirow[t]{2}{*}{3} & 0 & 2.9 & 4.4 & 3.0 & 1.1 \\
\hline & 3 & & & & \\
\hline \multicolumn{6}{|l|}{ 1:Lu; 2:La } \\
\hline 0.09 & 0.03 & 1.6 & 1.0 & 1.3 & 2.5 \\
\hline
\end{tabular}




\begin{tabular}{|c|c|c|c|c|c|}
\hline \multirow[t]{2}{*}{$C_{\text {init }}(\operatorname{Ln}(1)) \operatorname{meq} \mathrm{L}^{-1}$} & \multirow[t]{2}{*}{$C_{\text {init }}(\operatorname{Ln}(2))$ meq $\mathrm{L}^{-1}$} & \multicolumn{4}{|c|}{ Ratio values of $K_{d}(\operatorname{Ln}(1))$} \\
\hline & & FEBEX & HEC & MX80 & SCa-3 \\
\hline & 3 & & & & \\
\hline \multirow[t]{2}{*}{1} & 0.03 & 1.1 & 1.1 & 1.6 & 1.1 \\
\hline & 3 & & & & \\
\hline \multirow[t]{2}{*}{0.03} & 0 & 2.1 & 1.5 & 0.7 & 0.8 \\
\hline & 0.03 & & & & \\
\hline \multirow[t]{2}{*}{3} & 0 & 2.0 & 0.9 & 0.7 & 0.7 \\
\hline & 3 & & & & \\
\hline
\end{tabular}


Table 8. Fitting parameters derived from the Langmuir model. $b_{1}\left(\mathrm{meq} \mathrm{kg}^{-1}\right), K_{1}$ and $K_{2}\left(\mathrm{meq} \mathrm{L}^{-1}\right)$. (Ln (1): prediction of $\left.C_{\text {sorb }}(1)\right)$.

\begin{tabular}{|c|c|c|c|}
\hline & $b_{1}$ & $K_{1}$ & $K_{2}$ \\
\hline \multicolumn{4}{|l|}{ FEBEX } \\
\hline \multicolumn{4}{|c|}{ Water medium } \\
\hline $\mathrm{La}(1) ; \mathrm{Lu}(2)$ & 1150 & 29 & 24 \\
\hline $\mathrm{Lu}(1) ; \mathrm{La}(2)$ & 1056 & 26 & 21 \\
\hline \multicolumn{4}{|l|}{ Ca medium } \\
\hline $\mathrm{La}(1) ; \mathrm{Lu}(2)$ & 942 & 0.5 & 0.3 \\
\hline $\mathrm{Lu}(1) ; \mathrm{La}(2)$ & 2719 & 0.3 & 0.2 \\
\hline \multicolumn{4}{|l|}{$H E C$} \\
\hline \multicolumn{4}{|c|}{ Water medium } \\
\hline $\mathrm{La}(1) ; \mathrm{Lu}(2)$ & 662 & 133 & 53 \\
\hline $\mathrm{Lu}(1) ; \mathrm{La}(2)$ & 864 & 15 & 7.0 \\
\hline \multicolumn{4}{|l|}{ Ca medium } \\
\hline $\mathrm{La}(1) ; \mathrm{Lu}(2)$ & 647 & 0.6 & 1.9 \\
\hline $\mathrm{Lu}(1) ; \mathrm{La}(2)$ & 1833 & 1.0 & 0.4 \\
\hline \multicolumn{4}{|l|}{$M X 80$} \\
\hline \multicolumn{4}{|c|}{ Water medium } \\
\hline $\mathrm{La}(1) ; \mathrm{Lu}(2)$ & 872 & 13 & 10 \\
\hline $\mathrm{Lu}(1) ; \mathrm{La}(2)$ & 988 & 5.5 & 4.1 \\
\hline \multicolumn{4}{|l|}{ Ca medium } \\
\hline $\mathrm{La}(1) ; \mathrm{Lu}(2)$ & 772 & 0.8 & 1.8 \\
\hline $\mathrm{Lu}(1) ; \mathrm{La}(2)$ & 2412 & 0.4 & 0.2 \\
\hline \multicolumn{4}{|l|}{$S C a-3$} \\
\hline \multicolumn{4}{|c|}{ Water medium } \\
\hline $\mathrm{La}(1) ; \mathrm{Lu}(2)$ & 1301 & 16 & 14 \\
\hline $\mathrm{Lu}(1) ; \mathrm{La}(2)$ & 1280 & 29 & 21 \\
\hline \multicolumn{4}{|l|}{ Ca medium } \\
\hline $\mathrm{La}(1) ; \mathrm{Lu}(2)$ & 1062 & 0.6 & 0.4 \\
\hline $\mathrm{Lu}(1) ; \mathrm{La}(2)$ & 2101 & 0.8 & 0.2 \\
\hline
\end{tabular}


Figure 1
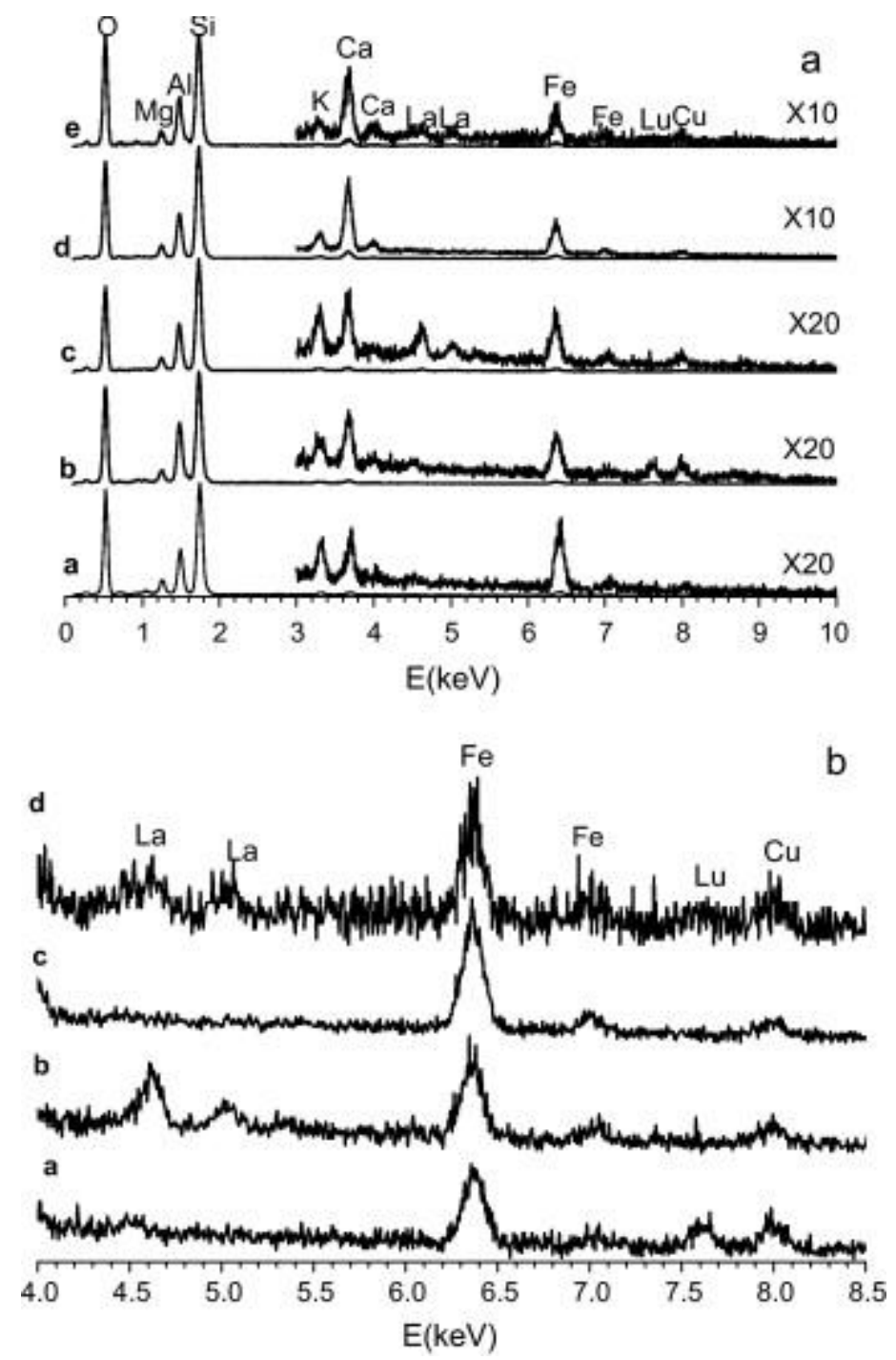
Figure 2
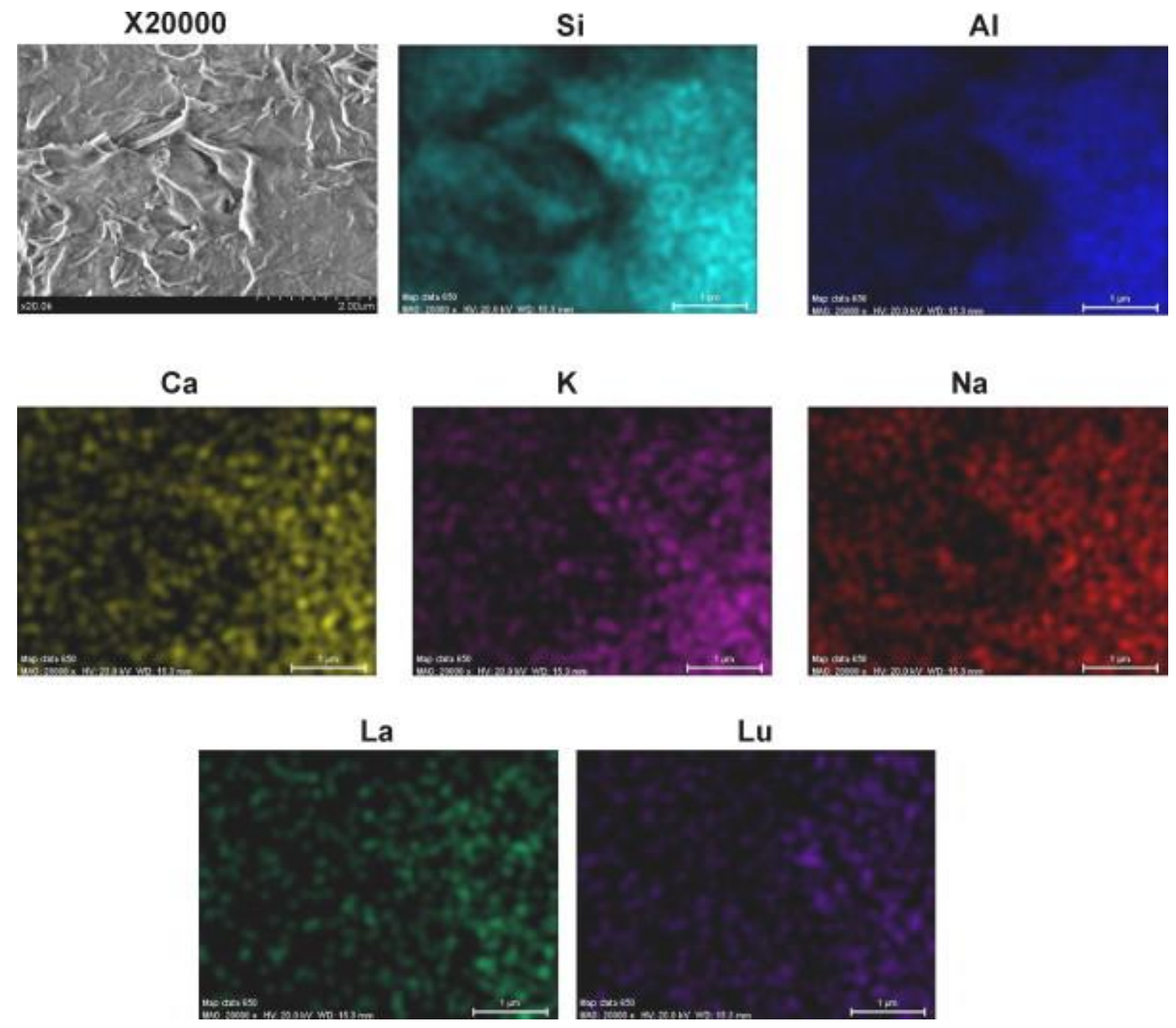
Figure 3
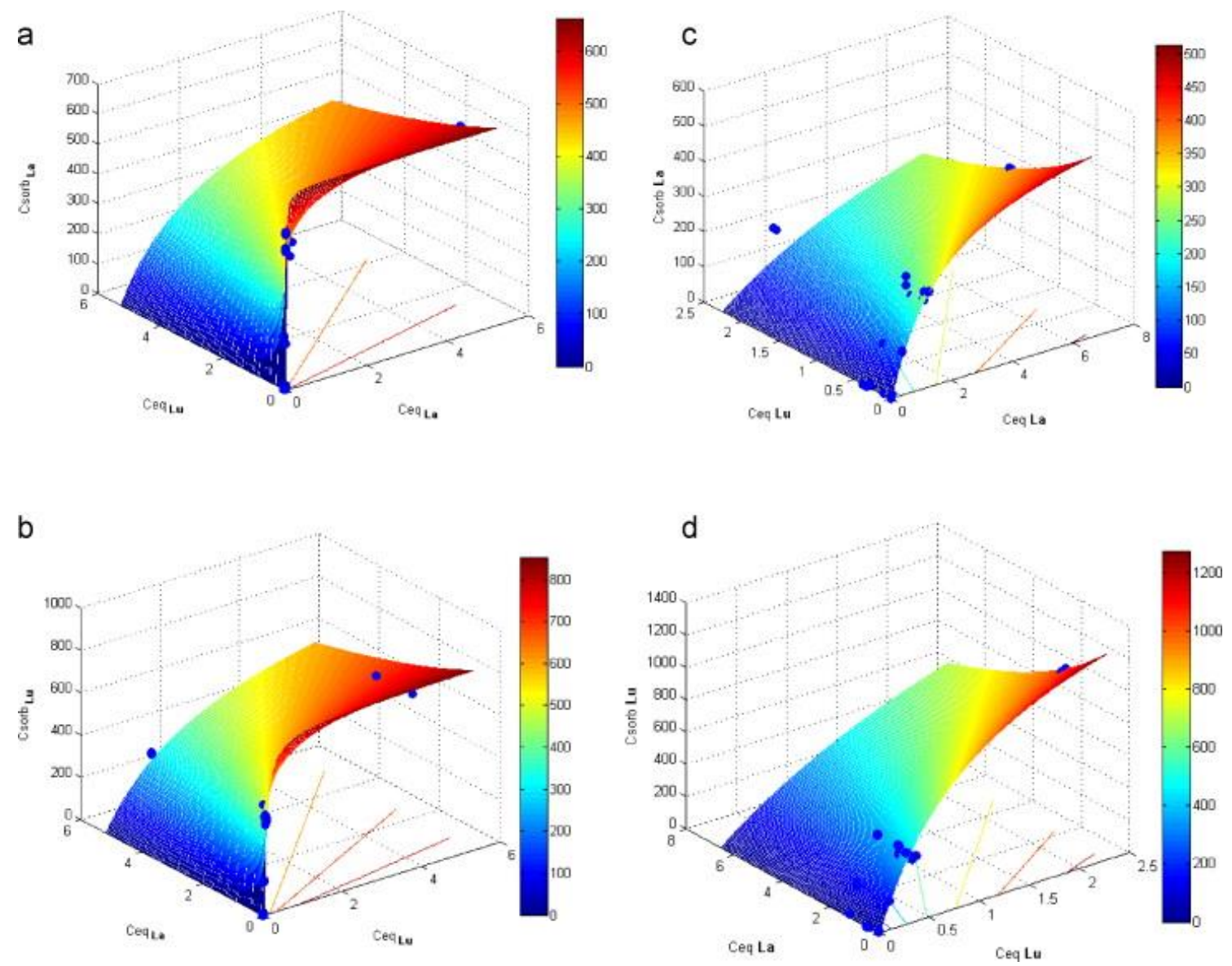